\title{
Hemoglobin Variants: Biochemical Properties and Clinical Correlates
}

\author{
Christopher S. Thom ${ }^{1,2}$, Claire F. Dickson ${ }^{3}$, David A. Gell ${ }^{3}$, and Mitchell J. Weiss ${ }^{2}$ \\ ${ }^{1}$ Cell and Molecular Biology Graduate Group, University of Pennsylvania School of Medicine, \\ Philadelphia, Pennsylvania 19104 \\ ${ }^{2}$ Hematology Department, Children's Hospital of Philadelphia, Philadelphia, Pennsylvania 19104 \\ ${ }^{3}$ Menzies Research Institute, University of Tasmania, Hobart, Australia \\ Correspondence: weissmi@email.chop.edu
}

Diseases affecting hemoglobin synthesis and function are extremely common worldwide. More than 1000 naturally occurring human hemoglobin variants with single amino acid substitutions throughout the molecule have been discovered, mainly through their clinical and/or laboratory manifestations. These variants alter hemoglobin structure and biochemical properties with physiological effects ranging from insignificant to severe. Studies of these mutations in patients and in the laboratory have produced a wealth of information on hemoglobin biochemistry and biology with significant implications for hematology practice. More generally, landmark studies of hemoglobin performed over the past 60 years have established important paradigms for the disciplines of structural biology, genetics, biochemistry, and medicine. Here we review the major classes of hemoglobin variants, emphasizing general concepts and illustrative examples.

G lobin gene mutations affecting hemoglobin $(\mathrm{Hb})$, the major blood oxygen $\left(\mathrm{O}_{2}\right)$ carrier, are common, affecting an estimated $7 \%$ of the world's population (Weatherall and Clegg 2001; Kohne 2011). These mutations are broadly subdivided into those that impair globin protein subunit production (thalassemias) and those that produce structurally abnormal globin proteins ( $\mathrm{Hb}$ variants). The latter class is mainly composed of missense mutations that cause single amino acid substitutions in the globin protein, resulting in an abnormal, or "variant" $\mathrm{Hb}$ tetramer. Less commonly, $\mathrm{Hb}$ variants are associated with deletions, multiple amino acid sub- stitutions, antitermination mutations, and altered posttranslational processing (Table 1).

Naturally occurring $\mathrm{Hb}$ mutations cause a range of biochemical abnormalities, some of which produce clinically significant symptoms. The most common and medically important $\mathrm{Hb}$ variants include $\mathrm{HbS}$ (Cao and Kan 2012; Lettre 2012; Schechter and Elion 2012; Serjeant and Rodgers 2012; Williams and Weatherall 2012), HbC (Cao and Kan 2012; Lettre 2012; Schechter and Elion 2012; Serjeant and Rodgers 2012; Williams and Weatherall 2012), HbE (see the sections on Selected Variants that Illustrate Important Aspects of Hemoglobin Biology and

Editors: David Weatherall, Alan N. Schechter, and David G. Nathan

Additional Perspectives on Hemoglobin and Its Diseases available at www.perspectivesinmedicine.org

Copyright (C) 2013 Cold Spring Harbor Laboratory Press; all rights reserved; doi: 10.1101/cshperspect.a011858

Cite this article as Cold Spring Harb Perspect Med 2013;3:a011858 


\section{C.S. Thom et al.}

Table 1. $\mathrm{Hb}$ variants that are discussed in this article

\begin{tabular}{|c|c|c|c|c|c|}
\hline Name & $\begin{array}{l}\text { Globin site } \\
\text { (fold) }\end{array}$ & $\begin{array}{l}\text { Amino acid } \\
\text { substitution }\end{array}$ & $\begin{array}{l}\text { Molecular } \\
\text { mechanism }\end{array}$ & Clinical phenotype & $\begin{array}{c}\text { Other biochemical } \\
\text { and laboratory findings }\end{array}$ \\
\hline \multicolumn{6}{|c|}{ Unstable Mutants } \\
\hline Brockton & $\beta 138(\mathrm{H} 16)$ & Ala $>$ Pro & $\begin{array}{l}\text { Altered secondary } \\
\text { structure }\end{array}$ & $\begin{array}{l}\text { Hemolytic anemia, } \\
\text { reticulocytosis }\end{array}$ & \\
\hline Philly & $\beta 35(\mathrm{C} 1)$ & Tyr $>$ Phe & $\begin{array}{l}\text { Altered } \alpha 1 \beta 1 \\
\quad \text { interface }\end{array}$ & $\begin{array}{l}\text { Hemolytic anemia, } \\
\text { reticulocytosis }\end{array}$ & $\begin{array}{l}\text { Decreased cooperativity, } \\
\text { increased oxygen } \\
\text { affinity }\end{array}$ \\
\hline Peterborough & $\beta 111$ (G13) & Val $>$ Phe & $\begin{array}{l}\text { Altered } \alpha 1 \beta 1 \\
\text { interface }\end{array}$ & $\begin{array}{l}\text { Hemolytic anemia, } \\
\text { reticulocytosis }\end{array}$ & $\begin{array}{l}\text { Decreased oxygen } \\
\text { affinity }\end{array}$ \\
\hline Stanmore & $\beta 111$ (G13) & $\mathrm{Val}>\mathrm{Ala}$ & $\begin{array}{l}\text { Altered } \alpha 1 \beta 1 \\
\text { interface }\end{array}$ & Hemolytic anemia & $\begin{array}{l}\text { Decreased oxygen } \\
\text { affinity }\end{array}$ \\
\hline J-Guantanamo & $\beta 128(\mathrm{H} 6)$ & Ala $>$ Asp & $\begin{array}{l}\text { Altered } \alpha 1 \beta 1 \\
\text { interface }\end{array}$ & Hemolytic anemia & Target cells \\
\hline Khartoum & $\beta 124(\mathrm{H} 2)$ & Pro $>$ Arg & $\begin{array}{l}\text { Altered } \alpha 1 \beta 1 \\
\text { interface }\end{array}$ & Normal & \\
\hline Prato & $\begin{array}{l}\alpha 1 \text { or } \alpha 231 \\
\quad(\mathrm{~B} 12)\end{array}$ & $\operatorname{Arg}>$ Ser & $\begin{array}{l}\text { Altered } \alpha 1 \beta 1 \\
\text { interface }\end{array}$ & $\begin{array}{l}\text { Anisocytosis, } \\
\text { hypochromia }\end{array}$ & $\begin{array}{l}\text { Mildly unstable in } \\
\text { isopropanol }\end{array}$ \\
\hline Lombard & $\begin{array}{rl}\alpha 2 & 103 \\
(\mathrm{G} 10)\end{array}$ & His $>$ Tyr & $\begin{array}{l}\text { Altered } \alpha 1 \beta 1 \\
\text { interface }\end{array}$ & Anemia & \\
\hline Contaldo & $\begin{array}{c}\alpha 1 \text { or } \alpha 2 \\
103 \\
(\mathrm{G} 10)\end{array}$ & His $>$ Arg & $\begin{array}{l}\text { Altered } \alpha 1 \beta 1 \\
\text { interface }\end{array}$ & Hemolytic anemia & \\
\hline Foggia & $\begin{array}{l}\alpha 2117 \\
\quad(\mathrm{GH} 5)\end{array}$ & Phe $>$ Ser & $\begin{array}{l}\text { Altered } \alpha 1 \beta 1 \\
\text { interface }\end{array}$ & Microcytosis & $\begin{array}{l}\text { Rapidly degraded } \alpha \\
\text { chains }\end{array}$ \\
\hline Groene Hart & $\begin{array}{r}\alpha 1119 \\
(\mathrm{H} 2)\end{array}$ & Pro $>$ Ser & $\begin{array}{l}\text { Altered } \alpha 1 \beta 1 \\
\text { interface, } \\
\text { disrupted AHSP } \\
\text { binding }\end{array}$ & $\begin{array}{l}\text { Hemolytic anemia, } \\
\text { microcytosis }\end{array}$ & \\
\hline Turriff & $\begin{array}{l}\alpha 1 \text { or } \alpha 299 \\
\quad(\mathrm{G} 6)\end{array}$ & Lys $>$ Glu & $\begin{array}{l}\text { Altered } \alpha 1 \beta 1 \\
\text { interface, } \\
\text { disrupted AHSP } \\
\text { binding }\end{array}$ & Normal & $\begin{array}{l}\text { Comigrates with } \mathrm{HbA}_{1 \mathrm{C}} \\
\text { rapidly degraded } \alpha \\
\text { chains }\end{array}$ \\
\hline Beziers & ג199 (G6) & Lys $>$ Asn & $\begin{array}{l}\text { Altered } \alpha 1 \beta 1 \\
\text { interface, } \\
\text { disrupted AHSP } \\
\text { binding }\end{array}$ & Normal & Comigrates with $\mathrm{HbA}_{1 \mathrm{C}}$ \\
\hline Hirosaki & $\begin{array}{l}\alpha 243 \\
\quad(\mathrm{CE} 1)\end{array}$ & Phe $>$ Leu & $\begin{array}{l}\text { Altered heme } \\
\text { pocket }\end{array}$ & $\begin{array}{l}\text { Heinz body hemolytic } \\
\text { anemia }\end{array}$ & Hyperunstable \\
\hline Terre Haute & $\beta 106$ (G8) & Leu $>$ Arg & $\begin{array}{l}\text { Altered heme } \\
\text { pocket }\end{array}$ & $\begin{array}{l}\text { Heinz body hemolytic } \\
\text { anemia, dominant } \\
\text { inclusion body } \\
\text { thalassemia }\end{array}$ & Hyperunstable \\
\hline \multicolumn{6}{|c|}{ High Affinity Variants } \\
\hline Kempsey & $\beta 99$ (G1) & Asp $>$ Asn & Unstable T state & Erythrocytosis & Decreased cooperativity \\
\hline Hiroshima & $\begin{array}{l}\beta 146 \\
(\mathrm{HC} 3)\end{array}$ & His $>$ Asp & $\begin{array}{l}\text { Mutated Bohr } \\
\text { proton donor }\end{array}$ & Erythrocytosis & $\begin{array}{r}\text { Decreased cooperativity, } \\
\text { decreased Bohr effect }\end{array}$ \\
\hline York & $\begin{array}{l}\beta 146 \\
(\mathrm{HC} 3)\end{array}$ & His $>$ Pro & $\begin{array}{l}\text { Mutated Bohr } \\
\text { proton donor }\end{array}$ & Erythrocytosis & $\begin{array}{r}\text { Decreased cooperativity, } \\
\text { decreased Bohr effect }\end{array}$ \\
\hline Cowtown & $\begin{array}{l}\beta 146 \\
(\mathrm{HC} 3)\end{array}$ & His $>$ Leu & $\begin{array}{l}\text { Mutated Bohr } \\
\text { proton donor }\end{array}$ & Erythrocytosis & Decreased Bohr effect \\
\hline
\end{tabular}


Hemoglobin Variants

Table 1. Continued

\begin{tabular}{|c|c|c|c|c|c|}
\hline Name & $\begin{array}{l}\text { Globin site } \\
\quad(\text { fold })\end{array}$ & $\begin{array}{l}\text { Amino acid } \\
\text { substitution }\end{array}$ & $\begin{array}{l}\text { Molecular } \\
\text { mechanism }\end{array}$ & Clinical phenotype & $\begin{array}{l}\text { Other biochemical } \\
\text { and laboratory findings }\end{array}$ \\
\hline Rahere & $\beta 82(\mathrm{EF} 6)$ & Lys $>$ Thr & $\begin{array}{l}\text { Altered 2,3DPG } \\
\text { binding site }\end{array}$ & Erythrocytosis & \\
\hline Providence & $\beta 82(\mathrm{EF} 6)$ & Lys $>$ Asn & $\begin{array}{l}\text { Altered 2,3DPG } \\
\text { binding site }\end{array}$ & Erythrocytosis & Low oxygen affinity \\
\hline Helsinki & $\beta 82(\mathrm{EF} 6)$ & Lys $>$ Met & $\begin{array}{l}\text { Altered 2,3DPG } \\
\text { binding site }\end{array}$ & Erythrocytosis & Decreased Bohr effect \\
\hline \multicolumn{6}{|c|}{ Low Affinity Variants } \\
\hline Kansas & $\beta 102(\mathrm{G} 4)$ & Asn $>\mathrm{Thr}$ & Unstable R state & Cyanosis & $\begin{array}{l}\text { Decreased } \\
\text { cooperativity }\end{array}$ \\
\hline Beth Israel & $\beta 102(\mathrm{G} 4)$ & Asn $>$ Ser & Unstable R state & Cyanosis & $\begin{array}{l}\text { Decreased } \\
\text { cooperativity }\end{array}$ \\
\hline St. Mandé & $\beta 102(\mathrm{G} 4)$ & Asn $>$ Tyr & Unstable R state & Cyanosis & \\
\hline \multicolumn{6}{|c|}{ Methemoglobin Variants } \\
\hline M-Iwate & $\begin{array}{c}\alpha 1 \text { or } \alpha 2 \\
\quad(\mathrm{~F} 8)\end{array}$ & His $>$ Tyr & Oxidized heme & $\begin{array}{l}\text { Pseudocyanosis } \\
\quad \text { (Methemoglobinemia) }\end{array}$ & $\begin{array}{l}\text { Abnormal visible } \\
\text { spectrum }\end{array}$ \\
\hline M-Saskatoon & $\beta 63$ (E7) & His $>$ Tyr & Oxidized heme & $\begin{array}{l}\text { Pseudocyanosis } \\
\quad \text { (Methemoglobinemia) }\end{array}$ & $\begin{array}{l}\text { Abnormal visible } \\
\text { spectrum }\end{array}$ \\
\hline \multicolumn{6}{|c|}{ Globin Chain Elongation Variants } \\
\hline $\begin{array}{r}\text { Constant } \\
\text { Spring }\end{array}$ & $\begin{array}{r}\alpha 2142 \\
\quad(\mathrm{HC} 3)\end{array}$ & $\begin{array}{l}\text { Stop }> \\
\text { Gln }\end{array}$ & $\begin{array}{l}\text { Antitermination } \\
\text { mutant }\end{array}$ & Microcytosis & $\begin{array}{l}\text { Decreased mRNA } \\
\text { stability }\end{array}$ \\
\hline Cranston & $\begin{array}{l}\beta 145 \\
(\mathrm{HC} 3)\end{array}$ & $+\mathrm{CT}$ & $\begin{array}{l}\text { Frameshift, } \\
\text { elongated } \\
\text { globin }\end{array}$ & Hemolytic anemia & $\begin{array}{l}\text { Increased oxygen } \\
\text { affinity, decreased } \\
\text { cooperativity }\end{array}$ \\
\hline \multicolumn{6}{|c|}{ Variants with Multiple Effects } \\
\hline $\mathrm{HbE}$ & $\beta 26(\mathrm{~B} 8)$ & Glu $>$ Lys & $\begin{array}{l}\text { Unstable, reduced } \\
\text { synthesis }\end{array}$ & Microcytosis & \\
\hline Bruxelles & $\begin{array}{l}\beta 41(\mathrm{C} 7) \text { or } \\
\beta 42 \\
(\mathrm{CD} 1)\end{array}$ & Phe $>0$ & $\begin{array}{l}\text { Altered heme } \\
\text { pocket }\end{array}$ & $\begin{array}{l}\text { Hemolytic anemia, } \\
\text { cyanosis, } \\
\text { splenomegaly, } \\
\text { reticulocytosis }\end{array}$ & $\begin{array}{l}\text { Heinz bodies, decreased } \\
\text { cooperativity }\end{array}$ \\
\hline Warsaw & $\beta 42(\mathrm{CD} 1)$ & Phe $>$ Val & $\begin{array}{l}\text { Altered heme } \\
\text { pocket }\end{array}$ & $\begin{array}{l}\text { Hemolytic anemia, } \\
\text { cyanosis }\end{array}$ & $\begin{array}{l}\text { Heinz bodies, } \\
\text { decreased } \\
\text { cooperativity }\end{array}$ \\
\hline Hammersmith & $\beta 42(\mathrm{CD} 1)$ & Phe $>$ Ser & $\begin{array}{l}\text { Altered heme } \\
\text { pocket }\end{array}$ & $\begin{array}{l}\text { Hemolytic anemia, } \\
\text { cyanosis }\end{array}$ & $\begin{array}{l}\text { Heinz bodies, } \\
\text { decreased } \\
\text { cooperativity }\end{array}$ \\
\hline $\begin{array}{l}\text { Buccuresti- } \\
\text { Louisville }\end{array}$ & $\beta 42(\mathrm{CD} 1)$ & Phe $>$ Leu & $\begin{array}{l}\text { Altered heme } \\
\text { pocket }\end{array}$ & $\begin{array}{l}\text { Hemolytic anemia, } \\
\text { cyanosis }\end{array}$ & $\begin{array}{l}\text { Heinz bodies, } \\
\text { decreased } \\
\text { cooperativity }\end{array}$ \\
\hline Zurich & $\beta 63$ (E7) & His $>$ Arg & $\begin{array}{l}\text { Altered heme } \\
\text { pocket }\end{array}$ & $\begin{array}{l}\text { Normal, but } \\
\text { hypersensitive to } \\
\text { oxidative stress }\end{array}$ & $\begin{array}{l}\text { Decreased cooperativity, } \\
\text { increased oxygen } \\
\text { affinity, increased CO } \\
\text { affinity }\end{array}$ \\
\hline Jamaica Plain & $\begin{array}{l}\beta 6(\mathrm{~A} 3) \\
\quad \text { and } \beta 68 \\
(\mathrm{E} 12)\end{array}$ & $\begin{array}{l}\text { Glu }>\text { Val } \\
\text { and Leu } \\
>\text { Phe }\end{array}$ & $\begin{array}{l}\text { Altered secondary } \\
\text { structure }\end{array}$ & $\begin{array}{l}\text { Hemolytic anemia, } \\
\text { cyanosis, } \\
\text { splenomegaly, splenic } \\
\text { sequestration }\end{array}$ & $\begin{array}{l}\text { Unstable, Heinz bodies, } \\
\text { sickle cell phenotype, } \\
\text { decreased oxygen } \\
\text { affinity }\end{array}$ \\
\hline
\end{tabular}


C.S. Thom et al.

Table 1. Continued

\begin{tabular}{|c|c|c|c|c|c|}
\hline Name & $\begin{array}{l}\text { Globin site } \\
\text { (fold) }\end{array}$ & $\begin{array}{l}\text { Amino acid } \\
\text { substitution }\end{array}$ & $\begin{array}{l}\text { Molecular } \\
\text { mechanism }\end{array}$ & Clinical phenotype & $\begin{array}{l}\text { Other biochemical } \\
\text { and laboratory findings }\end{array}$ \\
\hline Quebec-Chori & $\beta 87$ (F3) & Thr $>$ Ile & $\begin{array}{l}\text { Altered interaction } \\
\text { with HbS } \\
\text { polymer }\end{array}$ & Normal & $\begin{array}{l}\text { Promotes } \mathrm{HbS} \\
\text { polymerization }\end{array}$ \\
\hline D-Ibadan & $\beta 87(\mathrm{~F} 3)$ & Thr $>$ Lys & $\begin{array}{l}\text { Altered interaction } \\
\text { with } \mathrm{HbS} \\
\text { polymer }\end{array}$ & Normal & $\begin{array}{l}\text { Inhibits HbS } \\
\text { polymerization }\end{array}$ \\
\hline Bristol-Alesha & $\beta 67$ (E11) & $\mathrm{Val}>\mathrm{Met}$ & $\begin{array}{l}\text { Altered heme } \\
\text { pocket }\end{array}$ & $\begin{array}{l}\text { Hemolytic anemia, } \\
\text { reticulocytosis }\end{array}$ & $\begin{array}{l}\text { Heinz bodies, } \\
\text { decreased } \\
\text { cooperativity, } \\
\text { decreased Bohr effect, } \\
\text { decreased oxygen } \\
\text { affinity }\end{array}$ \\
\hline Toms River & $\gamma 67$ (E11) & $\mathrm{Val}>\mathrm{Met}$ & $\begin{array}{l}\text { Altered heme } \\
\text { pocket }\end{array}$ & Anemia, cyanosis & $\begin{array}{l}\text { Unstable, low oxygen } \\
\text { affinity }\end{array}$ \\
\hline
\end{tabular}

For a full listing of hemoglobin variants, see The Globin Gene Server (http://globin.bx.psu.edu; Hardison et al. 2002; Giardine et al. 2011).

Variants that Affect Multiple Hemoglobin Functions; see also Musallam et al. 2012), and some thalassemias (e.g., "thalassemic hemoglobinopathies"), all of which are under positive genetic selection because they confer survival advantages in areas where malaria is endemic (Weatherall and Clegg 2001). In addition to these prevalent mutant proteins, there are also $>1000$ other known naturally occurring $\mathrm{Hb}$ variants, which are rare individually but common collectively. Most $\mathrm{Hb}$ mutants are cataloged on the Globin Gene database (HbVar, http://globin. bx.psu.edu; Hardison et al. 2002; Giardine et al. 2011). By convention, these variants are named after the geographic origin of the affected individual. Although many $\mathrm{Hb}$ variants are clinically silent, some produce clinical manifestations of varying severity. Analyses of these variants, which can be considered to be "experiments of nature" (Garrod 1928), have generated valuable insights into structure-function relationships within the $\mathrm{Hb}$ molecule, with interesting and important clinical consequences.

The goal of this work is to provide a succinct conceptual framework for understanding the biology and clinical implications of $\mathrm{Hb}$ variants. We explore major concepts of $\mathrm{Hb}$ biology followed by a discussion of selected $\mathrm{Hb}$ variants that reinforce basic principles. For more exten- sive reviews of this topic, see Nathan and Oski's Hematology of Infancy and Childhood (Nathan et al. 2009); Hemoglobin: Molecular, Genetic, and Clinical Effects (Bunn and Forget 1986); Disorders of Hemoglobin: Genetics, Pathophysiology, and Clinical Management (Steinberg et al. 2001); and the Globin Gene database (Hardison et al. 2002; Giardine et al. 2011).

\section{BASIC PRINCIPLES}

Hemoglobin Synthesis, Structure, and Function

Hemoglobin is a heterotetramer composed of $\alpha$-like and $\beta$-like globin subunits, each bound to a heme prosthetic group. The major functions of $\mathrm{Hb}$ are to transport oxygen $\left(\mathrm{O}_{2}\right)$ from the lungs to peripheral tissues and carbon dioxide $\left(\mathrm{CO}_{2}\right)$ from the tissues to the lungs. The kinetics of $\mathrm{Hb}-\mathrm{O}_{2}$ binding and release are fine-tuned for this purpose and adaptable according to developmental ontogeny and metabolic perturbations. Moreover, the Hb molecule must limit potential problems caused by its associated iron and free $\mathrm{O}_{2}$, reactive molecules capable of inflicting damage through the production of reactive oxygen species. Efforts to understand how $\mathrm{Hb}$ structure imparts these critical functions have 
been ongoing for more than 50 years. Hemoglobin was one of the first proteins to be sequenced (Konigsberg et al. 1961; Schroeder et al. 1961; Watson and Kendrew 1961) and the globin genes were among the earliest to be cloned (Rabbitts 1976). In the late 1950s, Perutz and colleagues determined the three-dimensional structure of Hb through X-ray crystallography (Perutz 1960; Perutz et al. 1960). More recent studies refined this structure to high resolution (Paoli et al. 1996; Park et al. 2006). In addition, $\mathrm{O}_{2}$ and other ligand-binding properties have been measured in detail for native $\mathrm{Hb}$ and many naturally occurring mutants. All of this work provides a substantial framework for defining the $\mathrm{O}_{2}$ delivery properties of $\mathrm{Hb}$, as well as the molecular consequences of variant mutations (see, for example, Lehmann 1957; Konigsberg and Lehmann 1965; Shimizu et al. 1965; Perutz and Lehmann 1968; Perutz 1970; Bunn and Forget 1986).

Globin polypeptides are synthesized from separate $\alpha$-like and $\beta$-like globin gene clusters located on human chromosomes 16 and 11, respectively. Nascent globin chains rapidly incorporate heme, which stabilizes their native folding into $\mathrm{Hb}$ subunits composed of seven or eight $\alpha$ helices named $\mathrm{A}-\mathrm{H}$, which fold together into a globular structure (Fig. $1 \mathrm{~A}$ ). $\mathrm{Hb}$ subunits bind $\mathrm{O}_{2}$ and other ligands via the heme iron buried within an evolutionarily conserved hydrophobic pocket that faces the outside of HbA tetramers (Fig. 1B). Heme iron is axially coordinated to globin proteins by an invariant histidine residue in helix F8, termed the "proximal" histidine (Fig. 1C). The opposite axial position binds $\mathrm{O}_{2}$, which is stabilized by interaction with the conserved "distal" histidine in helix E7 (Fig. 1C). Multiple additional amino acids within the globin proteins stabilize heme binding through noncovalent interactions (Fig. $1 \mathrm{C}$ ). Iron must be in its reduced (ferrous, $\mathrm{Fe}^{2+}$ ) state for $\mathrm{Hb}$ to bind $\mathrm{O}_{2}$. Oxidized or "met" $\mathrm{Hb}$ (ferric, $\mathrm{Fe}^{3+}$ ) cannot bind $\mathrm{O}_{2}$ and is relatively unstable, tending to lose hemin and denature. Thus, red blood cells have evolved elaborate mechanisms to maintain $\mathrm{Hb}$ in its reduced state (Bunn and Forget 1986; Ganz and Nemeth 2012; Schechter 2012). For example, the methemoglobin reductase system converts methemo- globin (metHb) to its reduced form. Not surprisingly, globin mutations that alter amino acids within the ligand pocket frequently produce strong functional effects, including destabilization, altered affinity for $\mathrm{O}_{2}$, and increased rates of metHb formation and heme loss (see the section on Selected Variants that Illustrate Important Aspects of Hemoglobin Biology). Variants promoting autoxidation are termed "M-Hbs" (see the sections on Selected Variants that Illustrate Important Aspects of Hemoglobin Biology and Methemoglobin ("M-Type") Variants). Because $\mathrm{Hb}$ gains its distinctive color from the heme group, alterations that affect the environment of the heme iron, including changes in the surrounding amino acids, different gas ligands, or redox state, produce characteristic changes in visible light absorption. These color changes are used clinically to assess $\mathrm{Hb}-\mathrm{O}_{2}$ saturation, metHb formation and the effects of $\mathrm{Hb}$ variants.

Within the $\mathrm{Hb}$ tetramer, each globin subunit binds the unlike chain through two distinct interfaces, termed $\alpha 1 \beta 1$ and $\alpha 1 \beta 2$ (Fig. 1D). Individual globin subunits form dimers through the extremely high affinity $\alpha 1 \beta 1$ interaction. Globin chain monomers are relatively unstable compared with dimers, with a tendency to form intracellular precipitates that damage erythrocytes, causing hemolytic anemia. Thus, mutations that impair the $\alpha 1 \beta 1$ interaction can cause erythrotoxicity by favoring the accumulation of monomeric subunits (Fig. 2C). The $\alpha 1 \beta 2$ interaction, which is lower affinity, mediates tetramerization. Oxygen binding destabilizes the $\alpha 1 \beta 2$ interaction, resulting in a transition of the quaternary structure from the " $\mathrm{T}$ " (tense, low affinity, deoxygenated) to " $\mathrm{R}$ " (relaxed, high affinity, oxygenated) state, which facilitates $\mathrm{O}_{2}$ binding to additional subunits (Fig. 2A). This process causes cooperative $\mathrm{O}_{2}$ binding, which is illustrated by the characteristic sigmoidal shape of the $\mathrm{Hb}-\mathrm{O}_{2}$ equilibrium curve (Fig. 2B). Cooperativity allows maximal $\mathrm{O}_{2}$ release over relatively small drops in $\mathrm{O}_{2}$ tension. Mutations within the $\alpha 1 \beta 2$ interaction region can alter the functional properties of $\mathrm{Hb}$, mainly by perturbing $\mathrm{O}_{2}$-binding characteristics (Fig. 2C, cyan spheres; Table 1). 


\section{C.S. Thom et al.}

A

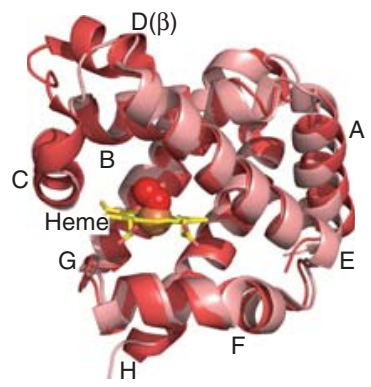

C

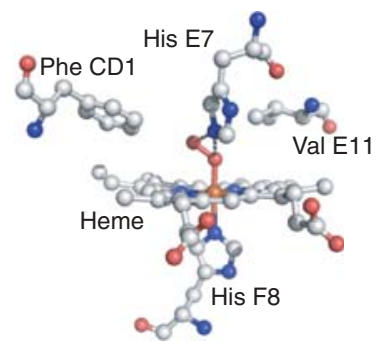

D

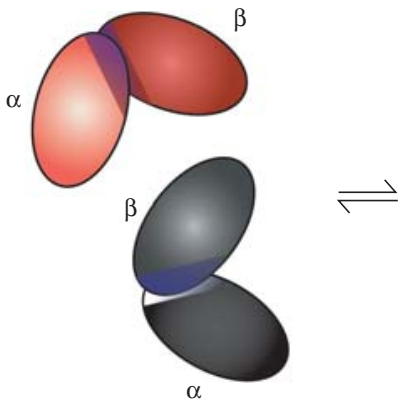

B
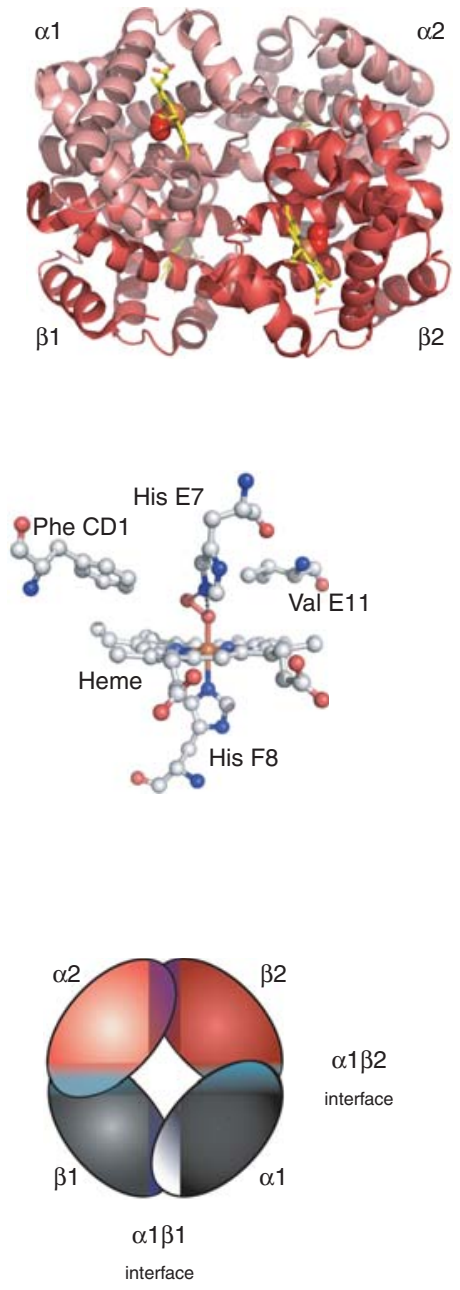

Figure 1. The structure of $\mathrm{Hb}$. (A) The $\alpha$ (pink) and $\beta$ (red) $\mathrm{Hb}$ subunits have conserved $\alpha$-helical folds. Helices are labeled $\mathrm{A}-\mathrm{H}$ from the amino terminus. The $\alpha$ subunit lacks helix D. (B) The high $\mathrm{O}_{2}$ affinity $\mathrm{R}$ state quaternary structure of $\mathrm{Hb}$ with $\mathrm{O}_{2}$ (red spheres) bound at all four heme sites (protoporphyrin-IX as yellow sticks, with central iron atom as orange sphere). (C) Stereo (wall-eye) diagram of the heme pocket of $\beta$ showing the proximal (F8) and distal (E7) histidines and selected residues in the distal heme pocket that influence ligand binding and autoxidation. (D) Hb tetramer is assembled from two identical $\alpha \beta$ dimers (shown in red and gray for clarity). In the tetramer, each subunit makes contact with the unlike chain through a high affinity dimerization $\alpha 1 \beta 1$ interface and a lower affinity $\alpha 1 \beta 2$ dimer-tetramer interface (cyan).

Cooperativity represents a general phenomenon termed allosteric regulation, in which effector molecules control the properties of enzymes or other proteins by binding to regions that are distinct from the active sites. Several allosteric regulators, in addition to $\mathrm{O}_{2}$, influence the properties of $\mathrm{Hb}$. For example, $\mathrm{H}^{+}$binds $\mathrm{Hb}$ to promote $\mathrm{O}_{2}$ release in a process termed the
Bohr effect (Perutz et al. 1984). In peripheral tissues, abundant $\mathrm{CO}_{2}$ is taken up by red blood cells and metabolized by carbonic anhydrase to carbonic acid, resulting in the production of $\mathrm{H}^{+}$ and consequent $\mathrm{O}_{2}$ release. In contrast, relatively low $\mathrm{CO}_{2}$ and high $\mathrm{pH}$ in the lung favors $\mathrm{O}_{2}$ binding to $\mathrm{Hb}$. Additionally, $\mathrm{CO}_{2}$ forms carbamino adducts with the amino termini of both $\alpha$ and $\beta$ 


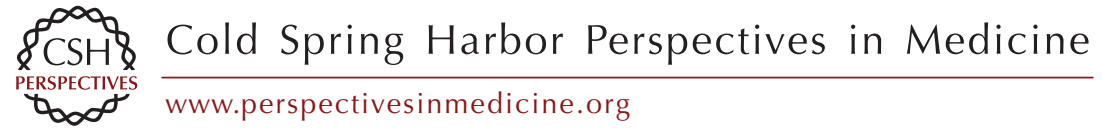

A

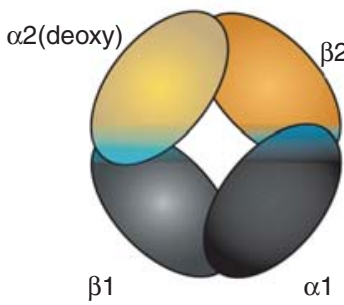

$\alpha 1$ $\alpha 2($ oxy $)$

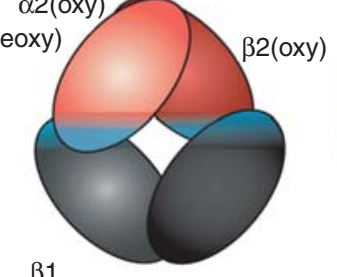

$\beta 1$

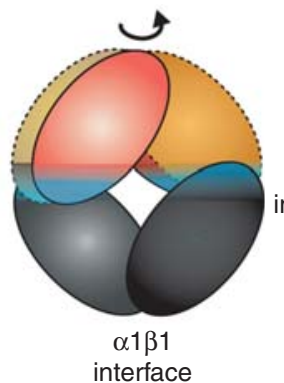

interface

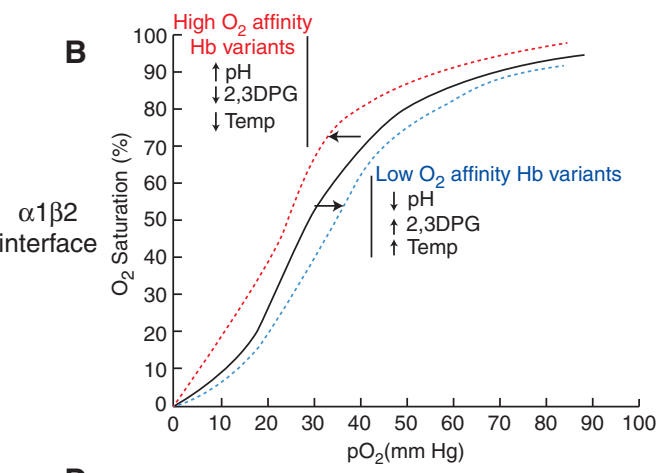

D

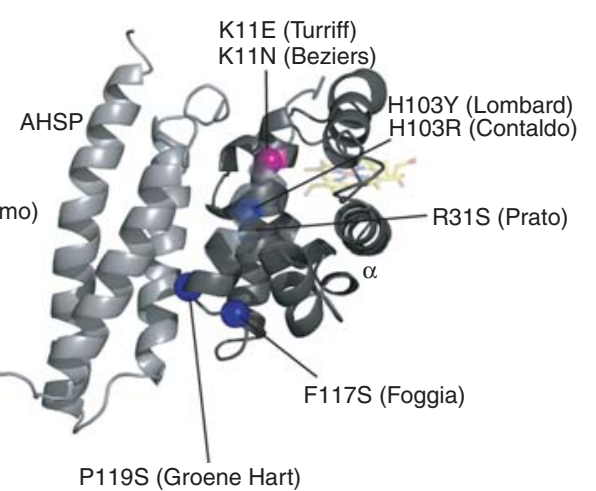

C

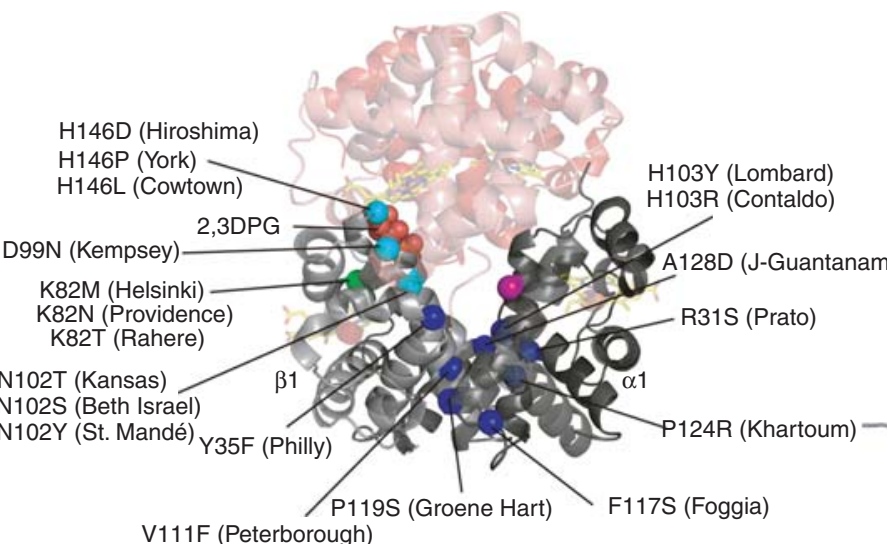

V111F (Peterborough)

Figure 2. Hb variants with altered subunit interactions. (A) Conversion from the low $\mathrm{O}_{2}$ affinity (deoxy, Tstate) to high $\mathrm{O}_{2}$ affinity (oxy, R state) involves a relative rotation of the $\alpha 1 \beta 1$ and $\alpha 2 \beta 2$ dimers, with changes in contacts across the $\alpha 1 \beta 2$ (and $\alpha 2 \beta 1$ ) interface (cyan). In this cartoon, the $\alpha 1 \beta 1$ dimer is held stationary to reveal the relative motion of the $\alpha 2 \beta 2$ dimer in going from the deoxy (orange) to the oxy (red) states. $(B)$ The sigmoidal shape of the $\mathrm{Hb}_{-} \mathrm{O}_{2}$ saturation curve shows allosteric regulation by changes in $\mathrm{pH}$, temperature, and 2,3DPG. These regulators, as well as Hb variants, influence the shape of the curve. High oxygen affinity variants, high $\mathrm{pH}$, low 2,3DPG, or low temperature induce a "left shift" in the saturation curve (red line). Conversely, low oxygen affinity variants, low $\mathrm{pH}$, high 2,3DPG, or high temperature induce a "right shift" (blue line). ( $C$ ) Hb sequence variants at the allosteric $\alpha 1 \beta 2$ interface (cyan spheres) show an impaired response to $\mathrm{O}_{2}$ binding. Some sequence variants disrupt binding to other allosteric regulators, e.g., substitutions at $\beta \mathrm{K} 82$ (green) disrupt interactions with 2,3DPG that normally stabilize the low $\mathrm{O}_{2}$ affinity T state. Mutations that disrupt $\alpha 1 \beta 1$ (and $\alpha 2 \beta 2$ ) dimerization (blue spheres) increase the concentration of free monomers, which are unstable. $(D)$ Some $\alpha$ mutations that disrupt binding to $\beta$ may also disturb binding to the chaperone, AHSP. Other $\alpha$ variants, such as Turriff and Beziers (pink sphere) may inhibit only AHSP binding. 


\section{C.S. Thom et al.}

globins in vivo. These interactions produce minor effects on whole blood $\mathrm{O}_{2}$ affinity compared to the impact of $\mathrm{CO}_{2}$ on $\mathrm{pH}$ (Bunn and Forget 1986). The compound 2,3-diphosphoglycerate (2,3DPG), formed as a by-product of glycolysis and present at relatively high concentrations in red blood cells, is another important allosteric regulator of $\mathrm{Hb}$. 2,3DPG binds and stabilizes T state $\mathrm{Hb}$ to facilitate $\mathrm{O}_{2}$ release. Hemoglobin binding sites for $\mathrm{H}^{+}$and 2,3DPG have been identified (Perutz et al. 1969, 1984; Perutz 1970; Arnone 1972). Together, these interactions allow $\mathrm{Hb}$ to sense metabolic activity and modulate $\mathrm{O}_{2}$ binding accordingly. This environmental sensory function can be altered by mutations that affect the affinity of $\mathrm{Hb}$ for its allosteric regulators (Fig. 2C, green sphere; Table 1).

\section{Identification of $\mathrm{Hb}$ Variants and Their Clinical Implications}

Many $\mathrm{Hb}$ variants are readily ascertained through physical examination and/or routine laboratory testing, which explains why so many have been discovered. Uncommonly, some variants are identified through evaluation of ill patients with severe anemia or clinically significant cyanosis. Many amino acid substitutions alter surface charge and are thus detected by electrophoresis or chromatography, techniques which are routinely performed on neonates in North America and Europe. Interestingly, a few $\mathrm{Hb}$ variants migrate similarly to $\mathrm{HbA}_{1 \mathrm{c}}$, a glycosylated form of $\mathrm{Hb}$ that reflects long-term control of blood glucose levels in diabetic patients (Table 1) (reviewed in Little and Roberts 2009). In this way, specific $\mathrm{Hb}$ amino acid substitutions can artificially elevate $\mathrm{HbA}_{1 \mathrm{c}}$ measurement and interfere with diabetic management. Other $\mathrm{Hb}$ variants are clinically benign but produce obvious changes in skin color. For example, mutations that increase $\mathrm{Hb}-\mathrm{O}_{2}$ affinity typically stimulate erythropoietic drive by inhibiting $\mathrm{O}_{2}$ tissue delivery, causing erythrocytosis associated with a ruddy complexion (Nathan et al. 2009). Mutations that reduce $\mathrm{O}_{2}$ affinity produce a bluish hue to the skin (cyanosis) caused by abnormally high levels of deoxyHb. Mutations that favor oxidation of $\mathrm{Hb}$ iron to the met form (M-Hbs), also cause blue-tinged skin, whereas the blood itself appears brown. Studies of one family with congenital cyanosis led Horlein and Weber to describe the first known hemoglobinopathy, caused by the variant Hb-M Saskatoon (Horlein and Weber 1948). The M-Hb variant Iwate, which causes "black blood" or "hereditary nigremia," was first described more than 200 years ago in Japan (Shibata et al. 1960).

It is important to note that many $\mathrm{Hb}$ variants affecting skin color are not clinically damaging beyond their cosmetic effects. However, these conditions can mimic more life-threatening problems such as cardiopulmonary and myeloproliferative disorders, which must be excluded. Thus, patients with cyanotic or polycythemic $\mathrm{Hb}$ variants may mistakenly undergo unnecessary and potentially dangerous medical procedures. Historical examples include cyanotic patients undergoing surgery or catheterization for presumed heart defects and polycythemic patients receiving radioactive ${ }^{32} \mathrm{P}$ for presumed polycythemia vera (Steinberg et al. 2001; Nathan et al. 2009). As stated, "the primary reason for establishing the diagnosis [of M Hbs] is to prevent iatrogenic misadventures that might arise under the mistaken impression that the patient has a cardiac or pulmonary disorder" (Bunn and Forget 1986). Most $\mathrm{Hb}$ variants with altered $\mathrm{O}_{2}$ affinity are relatively simple to diagnose through history, physical examination, and laboratory testing (Wajcman et al. 2001; Wajcman and Moradkhani 2011).

\section{Globin Gene Synthesis Is Developmentally Regulated}

Developmental regulation of the $\alpha$-like and $\beta$ like globin gene families is of great medical significance (Sankaran and Orkin 2012). Hemoglobin $F(\alpha 2 \gamma 2)$ is the most highly expressed form during late fetal gestation. After birth, expression gradually switches to $\mathrm{HbA}(\alpha 2 \beta 2)$ over several months. Thus, symptomatic mutations affecting $\alpha$ or $\gamma$ globins are present prenatally or at birth, whereas the manifestations of $\beta$-globin mutations are typically delayed until a few months after birth. Interestingly, $\gamma$-globin gene mutations that are apparent at birth, most 
typically reflected by cyanosis or hemolytic anemia (e.g., Hb-F Toms River, sections on Selected Variants that Illustrate Important Aspects of Hemoglobin Biology and Variants that Affect Multiple Hemoglobin Functions, and Table 1), fade over a few weeks as $\mathrm{Hb}$ production switches from $\mathrm{F}(\alpha 2 \gamma 2)$ to $\mathrm{A}(\alpha 2 \beta 2)$.

\section{Laboratory Testing for $\mathrm{Hb}$ Variants}

In many countries, routine testing of all newborns is performed to identify common hemoglobinopathies such as some thalassemias and HbS. Isoelectric focusing or high-performance liquid chromatography (HPLC), the most commonly used tests, identify most structurally abnormal Hbs (Wajcman et al. 2001). In this way, many benign $\mathrm{Hb}$ variants are discovered incidentally. Clinical indications for laboratory testing to investigate potential $\mathrm{Hb}$ variants are listed in Table 2.

Specific laboratory tests to investigate $\mathrm{Hb}$ variants include:

a. Physical methods of $\mathrm{Hb}$ separation. These include electrophoretic and chromatographic techniques that examine the physical properties of $\alpha 1 \beta 1$ dimers or individual globin subunits. Specific standards, such as $\mathrm{HbA}, \mathrm{HbS}, \mathrm{HbC}, \mathrm{HbF}$, and $\mathrm{HbA}_{2}$, are typically examined as controls. $\mathrm{Hb}$ variants may show altered migration in these assays. Historically, cellulose acetate and citrate agar electrophoresis were most commonly used to detect variant Hbs. Current clinical

Table 2. Clinical indications for laboratory testing to diagnose $\mathrm{Hb}$ variants

\begin{tabular}{l} 
Indications for hemoglobin testing \\
\hline Routine newborn testing for common \\
hemoglobinopathies (i.e., HbS, HbC, \\
thalassemias) \\
Cyanosis with adequate arterial oxygenation and no \\
apparent cardiopulmonary disease \\
Erythrocytosis with normal or elevated \\
erythropoietin levels \\
Unexplained hemolytic anemia \\
Unexplained thalassemia phenotype \\
Family history consistent with an Hb variant \\
\hline
\end{tabular}

testing more typically uses isoelectric focusing and HPLC, which are more sensitive.

b. $\mathrm{Hb}-\mathrm{O}_{2}$ binding curve. This test, performed on whole red blood cells or hemolysate, indicates the percent (\%) oxygenated $\mathrm{Hb}$ at a given $\mathrm{O}_{2}$ partial pressure (Fig. 2B). Hemoglobin variants with an abnormally high $\mathrm{O}_{2}$ affinity (see sections on Selected Variants that Illustrate Important Aspects of Hemoglobin Biology and High Oxygen Affinity Variants) will become saturated at lower $\mathrm{O}_{2}$ pressures producing a "left-shifted" $\mathrm{O}_{2}$ equilibrium curve, whereas mutations that reduce $\mathrm{O}_{2}$ affinity (see sections on Selected Variants that Illustrate Important Aspects of Hemoglobin Biology and Low Oxygen Affinity Variants) will cause the opposite "right shift." Determination of $\mathrm{Hb}-\mathrm{O}_{2}$ affinity responses to allosteric regulators, particularly 2,3DPG or $\mathrm{H}^{+}$( $\mathrm{pH}$ changes), can provide insight into the structural causes of the observed phenotypes. Unfortunately, few clinical laboratories currently offer this assay.

c. Visible wavelength spectroscopy. Hemoglobin variants with amino acid substitutions in the heme pocket affect visible light absorbance. For example, M-type Hbs show characteristic spectra that can distinguish them from methemoglobinemia caused by an enzyme deficiency in the metHb reductase system (Bunn and Forget 1986; Dailey and Meissner 2012; Ganz and Nemeth 2012; Schechter 2012). Pulse oximetry is a noninvasive spectrophotometric test that measures absorbance ratios at specific wavelengths for oxygenated $(660 \mathrm{~nm})$ and deoxygenated $(940 \mathrm{~nm})$ blood (Tremper and Barker 1989). This can produce confusing and sometimes misleading results in patients with variant $\mathrm{Hbs}$ that show unique light absorbance properties (Verhovsek et al. 2010). In these cases, analysis of arterial blood $\mathrm{O}_{2}$ concentration may be required to rule out hypoxia. Analyzing these variant Hbs using light absorbance throughout the full visible wavelength spectrum can provide useful diagnostic information. 
C.S. Thom et al.

d. Hemoglobin stability testing. Typically, $\mathrm{Hb}$ stability is impaired in variants that are associated with hemolytic anemia. Hemoglobin stability tests measure the propensity for $\mathrm{Hb}$ to denature on exposure to various stresses including heat (Carrell and Kay 1972), isopropanol (Bender et al. 1981), mechanical agitation (Asakura et al. 1975), and zinc acetate (Roth et al. 1976). The Heinz body test uses supravital stains, such as methylene blue or crystal violet, to detect aggregated globins within erythrocytes (Eisinger et al. 1985).

e. Specialized testing. Mass spectrometry analysis of patient hemolysate and DNA sequencing of globin genes are specialized confirmatory tests to identify amino acid and nucleotide alterations associated with suspected $\mathrm{Hb}$ variants (Wajcman et al. 2001; Wajcman and Moradkhani 2011). DNA sequencing may readily elucidate the presence of an $\mathrm{Hb}$ variant. However, additional biochemical and structural studies, including those discussed in this section, are required to determine how the variant affects $\mathrm{Hb}$ function. Crystallographic analysis is the highest resolution approach to determine the effects of globin amino acid substitutions on molecular structure. Crystallography has been used historically as a research tool to assess the effects of some interesting $\mathrm{Hb}$ variants (see, for example, Pulsinelli et al. 1973; Perutz et al. 1984).

\section{SELECTED VARIANTS THAT ILLUSTRATE IMPORTANT ASPECTS OF HEMOGLOBIN BIOLOGY}

\section{Unstable Variants}

Unstable variants frequently cause congenital Heinz body hemolytic anemia detected by laboratory screening and clinical symptoms (see sections on Basic Principles and Laboratory Testing for $\mathrm{Hb}$ Variants and Table 2). Mutations that alter any step in globin processing, including subunit folding, heme interaction, dimerization, or tetramerization, can destabilize $\mathrm{Hb}$. Bunn and Forget note five general mechanisms that destabilize Hbs: amino acid substitutions within the heme pocket, disruption of secondary structure, substitution in the hydrophobic interior of the subunit, amino acid deletions, and elongation of the subunit (Bunn and Forget 1986).

More than $75 \%$ of $\mathrm{Hb}$ is $\alpha$ helical (Perutz et al. 1960; Park et al. 2006). This structure is particularly susceptible to disruptions by proline substitutions (Levitt 1981). For example, in $\mathrm{Hb}$ Brockton ( $\beta 138$ [H16] Ala $>$ Pro) the substituted proline disrupts intermolecular hydrogen bonding between $\beta 138 \mathrm{Ala}$ and $\beta 134 \mathrm{Val}$ in helix H (Russu and Ho 1986; Moo-Penn et al. 1988). This produces an unstable variant with a propensity to precipitate and aggregate, thereby damaging erythrocytes and predisposing to hemolysis. Hb Brockton does not show altered $\mathrm{O}_{2}$ binding affinity or electrophoretic mobility shifts. This variant was identified by HPLC analysis of patient globin chains and its altered X-ray crystallography diffraction pattern shows local disruption of helix H (Moo-Penn et al. 1988).

Mutations at the $\alpha 1 \beta 1$ interface can cause hemolytic anemia by inhibiting heterodimer formation, favoring the accumulation of free globin subunits, which themselves are unstable, particularly $\alpha$ chains (Fig. 2C, blue spheres). Examples include $\mathrm{Hb}$ Philly ( $\beta 35$ [C1] Tyr $>$ Phe) (Rieder et al. 1969), Hb Peterborough ( $\beta 111$ [G13] Val > Phe) (King et al. 1972), Hb Stanmore ( $\beta 111$ [G13] Val > Ala) (Como et al. 1991), and Hb J-Guantanamo ( $\beta 128$ [H6] Ala $>$ Asp) (Martínez et al. 1977). Hb Khartoum $(\beta 124[\mathrm{H} 2]$ Pro $>$ Arg) contains a substitution at the $\alpha 1 \beta 1$ interface that is mildly destabilizing in vitro, but does not cause clinical symptoms (Clegg et al. 1969; Argos et al. 1979).

Interestingly, some $\alpha$-globin (HBA) gene mutations affecting the $\alpha 1 \beta 1$ interface may also destabilize free $\alpha$ chains by inhibiting their binding to $\alpha$-hemoglobin stabilizing protein (AHSP), an erythroid molecular chaperone that facilitates $\mathrm{Hb}$ assembly (Fig. 2D, blue spheres) (reviewed in Weiss et al. 2005; Favero and Costa 2011). These $\alpha$-globin variants include Hbs Prato ( $\alpha 1$ or $\alpha 231$ [B12] Arg $>$ Ser) (Marinucci et al. 1979), Lombard ( $\alpha 2103$ [G10] His > Tyr) (Hoyer et al. 2002), Contaldo 
$(\alpha 1$ or $\alpha 2103[\mathrm{G} 10]$ His $>$ Arg) (Sciarratta et al. 1984), Foggia ( $\alpha 2117$ [GH5] Phe $>$ Ser) (Lacerra et al. 2008), Groene Hart ( $\alpha 1119$ [H2] Pro $>$ Ser) (Harteveld et al. 2002; Vasseur-Godbillon et al. 2006; Giordano et al. 2007; Vasseur et al. 2009), and others (Wajcman et al. 2008; Yu et al. 2009). Naturally occurring $\alpha$-globin variants with amino acid substitutions at position 99 including Hb Turriff ( $\alpha 1$ or $\alpha 299$ [G6] Lys $>$ Glu) (Langdown et al. 1992) and Hb Beziers ( $\alpha 199$ [G6] Lys > Asn) (Lacan et al. 2004) bind $\beta$ globin normally but show impaired interaction with AHSP and may be mildly destabilizing (Fig. 2D, violet spheres) (see also Yu et al. 2009; Khandros et al. 2012; Mollan et al. 2012). Antitermination mutations can also destabilize $\alpha$ globin in part by impairing its binding to AHSP (Turbpaiboon et al. 2006).

Hyperunstable $\mathrm{Hb}$ variants precipitate shortly after synthesis and are not incorporated into $\mathrm{Hb}$ tetramers. These ephemeral proteins are difficult to isolate. In this case, electrophoresis may be falsely negative due to the rapid turnover of these variants, making DNA sequencing a critical diagnostic test. Affected patients show a dominantly inherited "inclusion body thalassemia" resulting from both the precipitated variant globin and consequent chain imbalance with accumulation of the unaffected globin, which is unstable in its free form (Stamatoyannopoulos et al. 1974). Patient erythrocytes typically display abnormal morphology with microcytosis, hypochromia, moderate to severe anisopoikilocytosis, basophilic stippling, and inclusions that may be become particularly prominent following splenectomy (Steinberg et al. 2001). Weatherall, Thein, and colleagues characterized several hyperunstable mutations in exon 3 of the $\beta$-globin gene (Thein et al. 1990). All of the mutations were frameshifts or nonsense codons that produced relatively long (>120 amino acid) proteins with carboxy-terminal truncations. The investigators proposed that truncated globins causing dominantly inherited thalassemia are long enough to bind heme posttranslationally, which rendered them relatively resistant to proteolytic degradation, allowing for subsequent precipitation of heme-containing aggregates detected as Heinz bodies. Missense mutations also cause hyperunstable $\mathrm{Hb}$ variants. Hb Hirosaki ( $\alpha 243$ [CE1] Phe $>$ Leu) was discovered in a family with hemolytic anemia (Ohba et al. 1975; Tanaka et al. 2005). After several tests failed to identify a soluble variant $\mathrm{Hb}$ within erythrocytes, DNA sequencing was used to characterize the mutation. Hb Terre Haute ( $\beta 106$ [G8] Leu > Arg) is another hyperunstable variant associated with a severe Heinz body hemolytic anemia and globin chain imbalance (Coleman et al. 1991). In initial studies of patient erythroid cells, performed in 1979, abnormal $\mathrm{Hb}$ tetramers were not detected and peptide mapping of radiolabeled nascent globins identified a $\beta 112$ (G14) Cys $>$ Arg substitution, originally termed $\mathrm{Hb}$ Indianapolis (Adams et al. 1979). However, the $\beta 112$ Cys $>$ Arg mutation was subsequently identified in unrelated individuals with much less severe disease. In 1991, reevaluation of the original pedigree by DNA analysis discovered a $\beta 106$ Leu $>$ Arg mutation, which was renamed $\mathrm{Hb}$ Terre Haute (Coleman et al. 1991). Most likely, incomplete tryptic cleavage of the abnormal $\beta$-globin peptide in the earlier studies led to misidentification of the causative mutation. This work reflects the interesting historical point that many $\mathrm{Hb}$ variants were identified through laborious and technically challenging protein studies performed some time ago, before DNA sequence analysis of patient globin genes was feasible. Reevaluation of these mutations through genetic testing has yielded some interesting surprises (see also the discussion on $\mathrm{Hb}$ Bristol-Alesha and the section on Variants that Affect Multiple Hemoglobin Functions).

\section{High Oxygen Affinity Variants}

Hemoglobin variants with increased $\mathrm{O}_{2}$ affinity cause erythrocytosis by stimulating erythropoietic drive (see Hebbel et al. 1978 for a description of the associated physiology). This commonly results from amino acid substitutions that stabilize the $\mathrm{R}$ (high $\mathrm{O}_{2}$ affinity) state relative to the $\mathrm{T}$ (low $\mathrm{O}_{2}$ affinity) state and/or inhibit responses to environmental allosteric regulators that stimulate $\mathrm{O}_{2}$ release, including $\mathrm{H}^{+}$(Bohr effect) or 2,3DPG (see the sections on 


\section{C.S. Thom et al.}

Basic Principles and Hemoglobin Synthesis, Structure, and Function). Because $\mathrm{T}$ to $\mathrm{R}$ state transitions are mediated largely through $\alpha 1 \beta 2$ interactions, high affinity variants frequently result from substitutions that alter this interface (Fig. 2C, cyan spheres). For example, the amino acid replacement in $\mathrm{Hb}$ Kempsey ( $\beta 99$ [G1] Asp $>$ Asn) perturbs $\alpha 1 \beta 2$ interactions by preventing the formation of a hydrogen bond between $\beta 99$ Asp and $\alpha 42$ Tyr, which normally stabilizes the deoxygenated low $\mathrm{O}_{2}$ affinity T state (Fig. 3) (Reed et al. 1968; Lindstrom et al. 1973; Bunn et al. 1974). This structural change shifts quaternary equilibrium toward the oxygenated $\mathrm{R}$ form, which impairs $\mathrm{O}_{2}$ release to peripheral tissues and thus increases erythropoietic drive. The carboxyl termini of globin chains are also involved in $\alpha 1 \beta 2$ interactions that stabilize the low $\mathrm{O}_{2}$ affinity $\mathrm{T}$ state and numerous substitutions within these regions cause high $\mathrm{O}_{2}$ affinity variants. In addition, $\beta 146$ His at the carboxyl terminus contributes significantly to the Bohr effect by forming a salt bridge with $\beta 94$ Asp (Perutz et al. 1984). This interaction is disrupted in several high $\mathrm{O}_{2}$ affinity variants with $\beta 146$ substitutions: Hb Hiroshima ( $\beta 146$ [HC3] His $>$ Asp) (Hamilton et al. 1969; Perutz et al. 1971; Imai et al. 1972; Olson et al. 1972), Hb York ( $\beta 146$ [HC3] His > Pro) (Bare et al. 1976), and $\mathrm{Hb}$ Cowtown ( $\beta 146$ [HC3] His $>$ Leu) (Fig. 2C) (Schneider et al. 1979; Perutz et al. 1984). These variants show reduced Bohr effect with impaired release of $\mathrm{O}_{2}$ under acidic conditions.

Several high affinity $\mathrm{Hb}$ variants are caused by substitutions that inhibit interaction with 2,3DPG, which normally binds globin chains to stimulate $\mathrm{O}_{2}$ release (Fig. 2C). For example, Hb Rahere ( $\beta 82[\mathrm{EF} 6]$ Lys $>$ Thr) replaces an
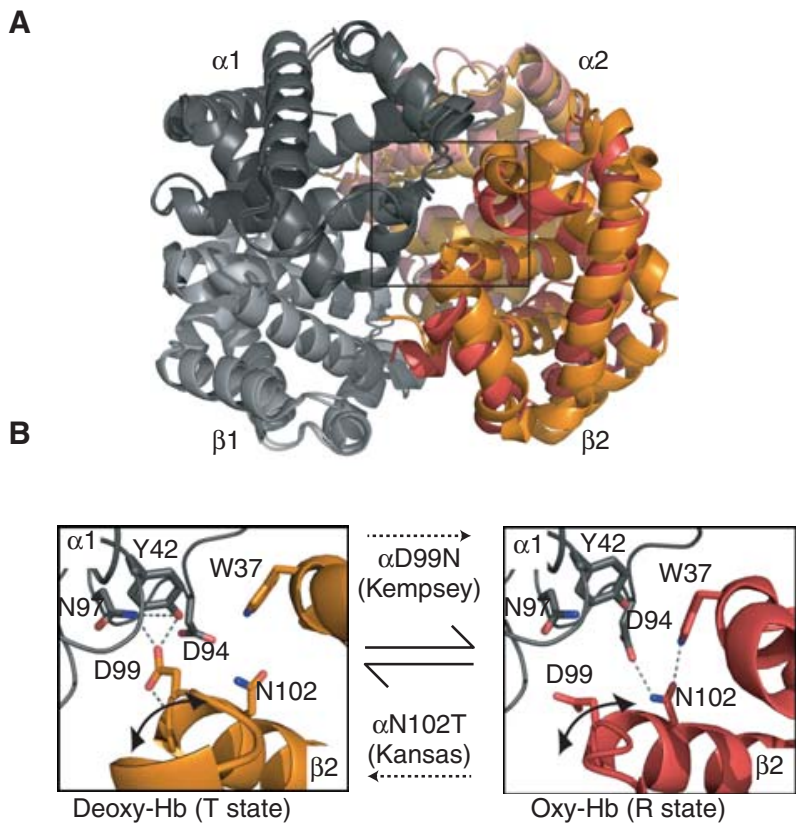

Figure 3. Hb variants that affect allosteric regulation. (A) The $\alpha 2$ and $\beta 2$ subunits indicated on the right side of the figure show an overlay of the R-state (red/pink) and T-state (orange/light orange) quaternary structures of $\mathrm{Hb}$. The allosteric $\alpha 1 \beta 2$ interface is boxed. $(B)$ Detail of the $\alpha 1 \beta 2$ interface in the deoxy T state ( $\beta 2$ chain in orange, PDB 2DN2) and oxy R state ( $\beta 2$ chain in red, PDB 2DN1) showing selected H-bonding interactions. Note that the two H-bonding networks use nonoverlapping sets of side chains, hence mutations in these residues affect only one state. Mutation of Asp99 to Asn (Hb Kempsey) compromises electrostatic interactions in the deoxygenated state, thereby favoring the $\mathrm{R}$ state and causing impaired $\mathrm{O}_{2}$ release. Mutation of Asn 102 to Thr (Hb Kansas) abrogates interactions with Asp94, favoring the $\mathrm{T}$ state and $\mathrm{O}_{2}$ binding inhibition. 
invariant lysine in the 2,3DPG binding site of $\beta$ globin, thereby reducing the affinity for this allosteric regulator (Lorkin et al. 1975; Sugihara et al. 1985). Consequently, Hb Rahere shows blunted $\mathrm{O}_{2}$ release in response to added $2,3 \mathrm{DPG}$ in vitro. In vivo, $\mathrm{O}_{2}$ release in peripheral tissues is inhibited, resulting in elevated blood $\mathrm{Hb}$ levels. Similarly, Hb Providence ( $\beta 82$ [EF6] Lys $>$ Asn) (Bonaventura et al. 1976; MooPenn et al. 1976) and Hb Helsinki ( $\beta 82$ [EF6] Lys > Met) (Ikkala et al. 1976; Charache et al. 1977) are high $\mathrm{O}_{2}$ variants caused by different amino acid substitutions at the 2,3DPG binding site on $\beta 82$.

\section{Low Oxygen Affinity Variants}

Low $\mathrm{O}_{2}$ affinity $\mathrm{Hb}$ variants typically present with cyanosis. In general, these variants are caused by globin amino acid substitutions that tip the quaternary equilibrium of $\mathrm{Hb}$ tetramers from the high affinity oxygenated $\mathrm{R}$ state to the low affinity deoxygenated T state; more or less the opposite of what occurs for high $\mathrm{O}_{2}$ affinity variants (see the sections on Selected Variants that Illustrate Important Aspects of Hemoglobin Biology and High Oxygen Affinity Variants). This does not inhibit $\mathrm{Hb}-\mathrm{O}_{2}$ release in tissue capillaries, but rather, interferes with $\mathrm{Hb}$ $\mathrm{O}_{2}$ uptake if the $\mathrm{P}_{50}$ has increased to $\geq 50 \mathrm{~mm}$ $\mathrm{Hg}$. Paradoxically, low $\mathrm{O}_{2}$ affinity $\mathrm{Hb}$ variants can be associated with mild anemia thought to be caused by increased $\mathrm{O}_{2}$ tissue delivery with reduced erythropoietic drive (Stamatoyannopoulos et al. 1969). In addition, some low $\mathrm{O}_{2}$ affinity mutants are unstable and therefore associated with not only cyanosis but also Heinz body hemolytic anemia (see the sections on Selected Variants that Illustrate Important Aspects of Hemoglobin Biology and Unstable Variants).

Several low affinity variants involve replacements at the $\alpha 1 \beta 2$ interface, which plays an important role in $\mathrm{Hb}$ cooperativity. $\mathrm{Hb}$ Kansas ( $\beta 102[\mathrm{G} 4]$ Asn $>$ Thr) is a well-studied low $\mathrm{O}_{2}$ affinity variant (Fig. 3B) (Reissmann et al. 1961; Bonaventura and Riggs 1968; Gibson et al. 1973; Riggs and Gibson 1973). Affected individuals are markedly cyanotic, although clinically well. Replacement of Asn 102 at the $\alpha 1 \beta 2$ interface inhibits the formation of a hydrogen bond with Asp94 that normally stabilizes the oxygenated $\mathrm{R}$ structure. A similar mechanism causes low $\mathrm{O}_{2}$ affinity in two other $\mathrm{Hb}$ variants through different substitutions of the same amino acid residue (B102 [G4] Asn) in $\mathrm{Hb}$ Beth Israel ( $\beta 102$ [G4] Asn > Ser) (Nagel et al. 1976) and $\mathrm{Hb}$ St. Mandé ( $\beta 102$ [G4] Asn > Tyr) (Arous et al. 1981; Poyart et al. 1990).

\section{Methemoglobin ("M-Type") Variants}

Hemoglobin iron must be in its reduced $\left(\mathrm{Fe}^{2+}\right.$, ferrous) state to bind $\mathrm{O}_{2}$. Moreover, oxidized $\left(\mathrm{Fe}^{3+}\right.$, ferric, met) $\mathrm{Hb}$ is intrinsically unstable with a tendency to release heme. Hemoglobin reduction is maintained through intrinsic features of the $\mathrm{Hb}$ protein and extrinsic antioxidant pathways within red blood cells (see the sections on Basic Principles and Hemoglobin Synthesis, Structure, and Function). Exposure to oxidant drugs or toxins, genetic alterations in erythroid metHb reductase enzyme systems (Ganz and Nemeth 2012; Schechter 2012), or globin chain variants can predispose to methemoglobinemia. These disorders present as "pseudocyanosis," (i.e., low $\mathrm{Hb}-\mathrm{O}_{2}$ saturation), despite adequate arterial oxygenation. Detailed in vitro analyses of the red cell and isolated $\mathrm{Hb}$ samples can usually distinguish wild-type metHb resulting from toxins or defective reductase systems and $\mathrm{M}$-type $\mathrm{Hb}$ variants that are predisposed to spontaneous oxidation (Bunn and Forget 1986; Steinberg et al. 2001; Nathan et al. 2009). For example, various M-Hbs show characteristic visible absorbance spectra.

Globin variants associated with metHb formation are typically caused by amino acid substitutions within the heme pocket. For example, four different $\mathrm{M}-\mathrm{Hb}$ occur when tyrosine replaces the $\alpha$ - or $\beta$-globin proximal or distal histidine residues that interact with heme (Fig. 1C) (reviewed in Adachi et al. 2011). In Hb M-Iwate ( $\alpha 1$ or $\alpha 287$ [F8] His $>$ Tyr), the proximal histidine is replaced by tyrosine (Fig. 4A), which deprotonates and coordinates to the heme iron (Fig. 4B) (Konigsberg and Lehmann 1965; Shimizu et al. 1965). Ferric heme, bound through the native $\mathrm{His} \mathrm{F} 8$, is readily reduced by metHb 


\section{C.S. Thom et al.}

reductase (Fig. 4C). Tyrosine (F8) coordination stabilizes the oxidized ferric state and decreases reactivity with metHb reductases. This interaction also distorts the position of heme and helix $\mathrm{F}$ within the altered $\alpha$ subunits. In native $\mathrm{Hb}$, movement of the proximal His F8 and F helix away from the heme group stabilizes the deoxygenated $\mathrm{T}$ state and reduces the $\mathrm{O}_{2}$ affinity of the native $\beta$ subunit partners. Hence, substitution of the normal His F8 side chain for a longer Tyr F8 (Fig. 4A) also stabilizes the deoxygenated T state and reduces $\mathrm{O}_{2}$ affinity of the native $\beta$ subunit in $\mathrm{Hb}$ M-Iwate (Nagai et al. 2000; Jin et al. 2004). These biochemical and structural alterations underlie the lack of cooperativity and severe cyanosis in patients with $\mathrm{Hb} \mathrm{M}$ Iwate, in which metHb levels can exceed 20\% (normal <2\%) (Ameri et al. 1999). In contrast, $\mathrm{Hb}$ M-Saskatoon ( $\beta 63$ [E7] His $>$ Tyr) replaces the distal His with Tyr (Fig. 4D) (Horlein and Weber 1948; Hayashi et al. 1966). In this variant, the protonated form of mutant Tyr can bind ferric heme iron to generate a hexacoordinate structure that is relatively easily reduced by cellular metHb reductases (Fig. 4E). Consequently, patients with $\mathrm{Hb} \mathrm{M}$-Saskatoon have lower levels of circulating oxidized $\mathrm{Hb}$ compared with those with $\mathrm{Hb} \mathrm{M}$-Iwate. Comparative studies of these patients and their variant $\mathrm{M}-\mathrm{Hb}$ have contributed greatly to understanding the biochemical properties of the heme iron, including its interactions with various ligands and nearby amino acids such as the proximal and distal histidines.

\section{Globin Chain Elongation Mutants}

Antitermination and frameshift mutations that add irrelevant amino acids to the carboxyl terminus of globin proteins produce interesting variants that can damage erythrocytes (Nathan et al. 2009). The most clinically significant
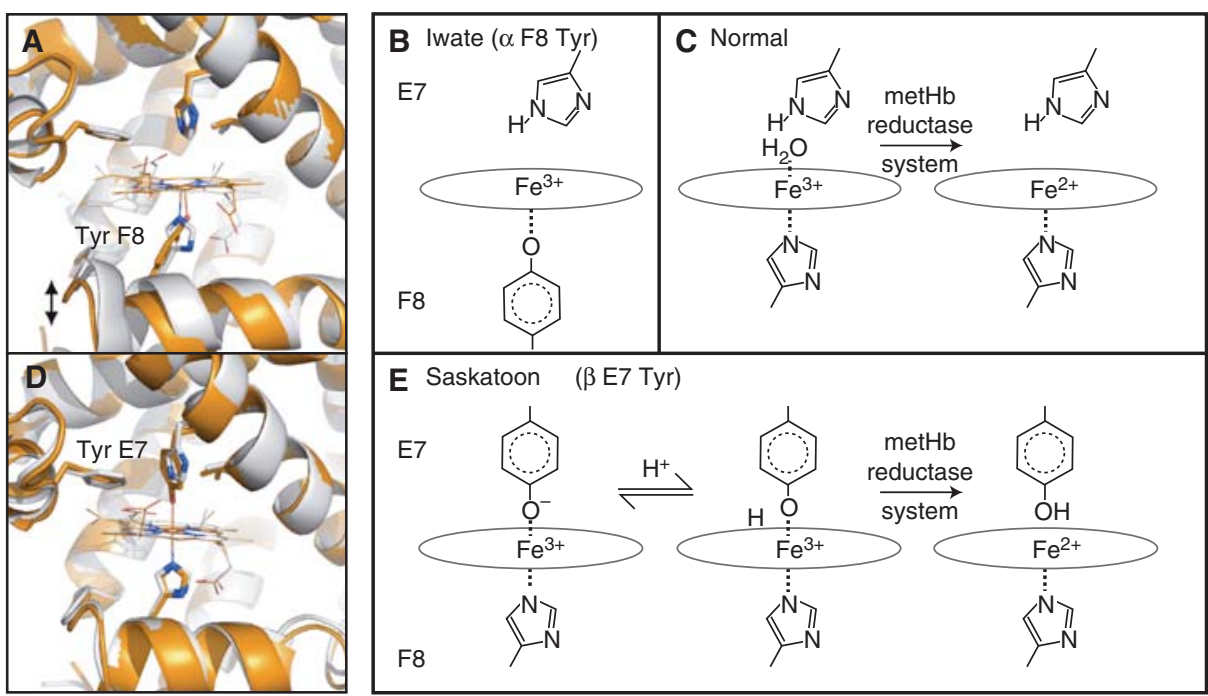

Figure 4. Examples of M-type hemoglobins. (A) The heme pocket of wild-type $\mathrm{Mb}$ (gray) and the F8 His $>\mathrm{Tyr}$ mutation (orange, PDB 1HRM), which serves as a model for Hb M-Iwate. Effects on the protein fold are to increase the distance from the heme to the F helix, recapitulating features of the deoxy- $\alpha$ (T state) structure. $(B)$ In $\mathrm{Hb} \mathrm{M}$-Iwate, $\alpha 87$ Tyr F8 is deprotonated and favors $\mathrm{Fe}^{3+}$ oxidation state, resulting in rapid autoxidation. This ferric form is not reduced by metHb reductase. $(C)$ With the normal His F8 present, ferric heme is readily reduced. (D) Substituting the distal His E7 side chain in Mb for a larger Tyr E7 (orange, PDB 1MGN), as also occurs in Hb Saskatoon, brings the Tyr hydroxyl group within binding distance of the iron, forming a hexacoordinate iron site. (E) In Hb Saskatoon the hexacoordinate ferric iron in the effected $\beta$ chains can be reduced by metHb reductase, possibly owing to a transient protonation of Tyr E7. Note that $\mathrm{Mb}$ is used as a model for $\mathrm{Hb}$ subunits in $A$ and $D$, whereas $B$ and $E$ are based on $\mathrm{Hb}$ spectroscopy. 
example is Hb Constant Spring ( $\alpha 2142$ [HC3] Stop $>$ Gln), caused by an antitermination $\mathrm{mu}-$ tation at the $\alpha 2$ stop codon (Clegg et al. 1971; Efremov et al. 1971; Milner et al. 1971; Clegg and Weatherall 1974). This elongates the protein by 31 amino acids, generating an unstable protein that is relatively underrepresented in hemolysates, but can be detected by physical methods (see sections on Basic Principles, Laboratory Testing for $\mathrm{Hb}$ Variants, and Physical methods of $\mathrm{Hb}$ separation). In addition, $\mathrm{Hb}$ Constant Spring mRNA is rapidly degraded in developing erythrocytes, owing to ribosomal entry into the $3^{\prime} \mathrm{UTR}$, causing displacement of RNA-bound stabilizing proteins with a resultant thalassemia syndrome (Hunt et al. 1982; Derry et al. 1984; Weiss and Liebhaber 1994; Morales et al. 1997).

$\mathrm{Hb}$ Constant Spring contributes to $\alpha$-thalassemia syndromes, particularly when combined with two $\alpha$-globin deletional alleles $\left(-/ \alpha^{\mathrm{CS}} \alpha\right)$, which produces a severe form of $\mathrm{HbH}$ disease (Viprakasit and Tanphaichitr 2002). Isolated $\mathrm{Hb}$ Constant Spring, in its heterozygous $(\alpha \alpha)$ $\left.\alpha^{\mathrm{CS}} \alpha\right)$ or homozygous $\left(\alpha^{\mathrm{CS}} \alpha / \alpha^{\mathrm{CS}} \alpha\right)$ forms, results in more severe anemia than occurs when the same $\alpha$ alleles are deleted $(\alpha \alpha /-\alpha)$ or $(-\alpha /-\alpha)$ (Schrier et al. 1997). This is due to the cytotoxic effects of the unstable Constant Spring protein. Although most common in Southeast Asia, Hb Constant Spring is increasingly identified in other geographic regions, largely through global migration (Lal et al. 2011). In fact, it was first discovered in a Chinese family living in Constant Spring, Jamaica.

One example of a $\beta$-globin chain elongation mutant is $\mathrm{Hb}$ Cranston $(\beta 145[\mathrm{HC} 3]+\mathrm{CT})$ (Bunn et al. 1975). This mutation introduces a frameshift at the normal stop codon to generate a $\beta$ chain that is extended by 11 amino acids. This results in an unstable $\mathrm{Hb}$ tetramer with high $\mathrm{O}_{2}$ affinity and diminished cooperativity (McDonald et al. 1980; Shaeffer et al. 1980). Affected patients show compensated hemolytic anemia with the variants accounting for 30\% of total $\mathrm{Hb}$ in the hemolysate. Interestingly, the structure of $\mathrm{Hb}$ Cranston was investigated simultaneously with studies to determine the $\beta$-globin mRNA $3^{\prime}$ untranslated sequence (For- get et al. 1975). Cross-comparison of the protein and mRNA sequencing data allowed Bunn, Forget, and colleagues to more rapidly define normal $\beta$-globin gene structures and ascertain that the $\mathrm{Hb}$ Cranston mutation likely arose by nonhomologous crossover of two normal $\beta$-globin genes.

\section{Variants that Affect Multiple Hemoglobin Functions}

Not surprisingly, amino acid substitutions within critical regions of globin proteins can produce multiple effects. For example, $\mathrm{HbE}$ ( $\beta 26$ [B8] Glu > Lys), a common variant in Southeast Asia, contains an amino acid substitution that renders $\beta$ chains mildly unstable in vitro with minimal clinical significance (Frischer and Bowman 1975; Huisman 1997; Rees et al. 1998; see also Musallam et al. 2012). However, this mutation also creates an alternate splice site in the $\beta$-globin mRNA, leading to reduced synthesis of productive transcripts with resultant thalassemia (Orkin et al. 1982). HbE is particularly deleterious when coinherited with a more severe $\beta$-thalassemic allele, which happens commonly in Southeast Asia.

Mutations that alter the heme pocket commonly produce multiple biochemical effects. For example, deletion or substitution of the conserved Phe residue at the CD1 helical region in the heme pocket markedly destabilizes the affected globin and also alters its $\mathrm{O}_{2}$ affinity. Thus, $\mathrm{Hb}$ Bruxelles ( $\beta 42$ [CD1] Phe $>0)$ (Blouquit et al. 1989; Griffon et al. 1996), Hb Warsaw $(\beta 42[\mathrm{CD} 1]$ Phe $>$ Val) (Honig et al. 1990), Hb Hammersmith ( $\beta 42$ [CD1] Phe > Ser) (Dacie et al. 1967), and Hb Buccuresti-Louisville ( $\beta 42$ [CD1] Phe $>$ Leu) (Bratu et al. 1971; Keeling et al. 1971) cause both congenital Heinz body hemolytic anemia and cyanosis. These combined effects arise from severely reduced cooperativity, rapid rates of autoxidation and hemin loss, and unfolding of these unstable globin variants (Griffon et al. 1996).

Another interesting heme pocket variant is Hb Zurich ( $\beta 63$ [E7] His $>$ Arg) in which the distal His is replaced by Arg (Huisman et al. 1961; Bachmann and Martihr 1962; Frick et al. 


\section{C.S. Thom et al.}

1962; Tucker et al. 1978; Phillips et al. 1981; Springer et al. 1989). The large, highly polar variant His side chain swings out of the distal heme pocket, and the positively charged guanidino group forms a salt bridge with a heme propionate (Fig. 5A). This results in an enlarged ligand-binding pocket, destabilizing $\mathrm{O}_{2}$ binding and causing iron autoxidation via exposure to water. Affected individuals show increased sensitivity to oxidant agents, including sulfa drugs, which more easily enter the expanded heme pocket. Loss of the distal histidine markedly decreases $\mathrm{O}_{2}$ affinity but has little effect on car- bon monoxide (CO) binding. As a result, individuals with $\mathrm{Hb}$ Zurich tend to have supranormal levels of $\mathrm{CO}-\mathrm{Hb}$, which ironically protects the heme iron from oxidation and the globin from denaturation. Affected subjects who are cigarette smokers accumulate even higher levels of CO-Hb, which tends to protect against hemolysis. Thus, "the pathology of a mutant protein is ameliorated by a normally toxic pollutant" (Bunn and Forget 1986).

Two other recently identified $\mathrm{Hb}$ variants illustrate how multiple biochemical defects produce unique phenotypes. Hb Jamaica Plain
A

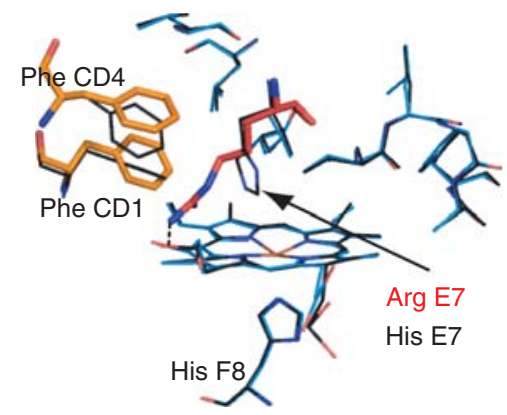

B

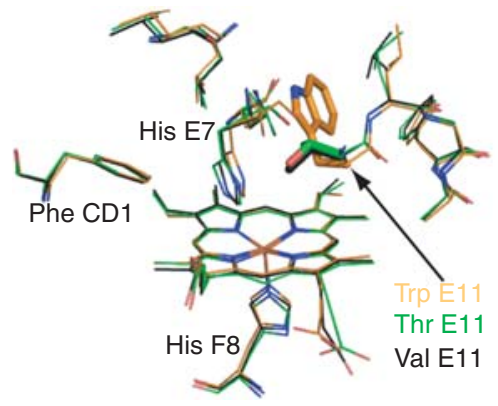

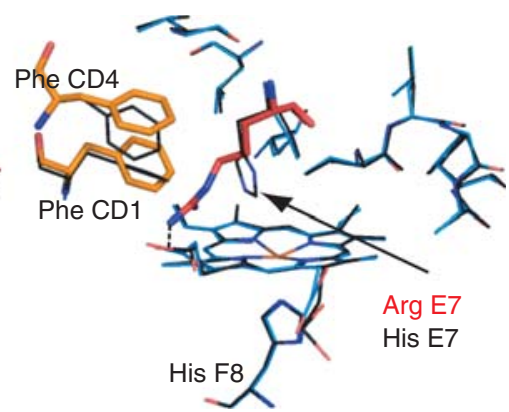

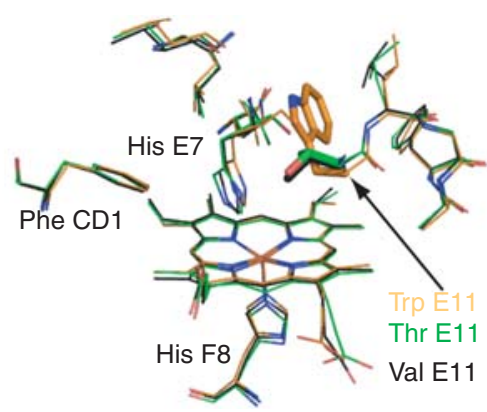

Figure 5. Hb variants with amino acid changes in the heme pocket. (A) Stereo diagram of a model of the deoxy $\mathrm{Hb}$ Zurich $\beta$ heme pocket (blue) overlaid with the wild-type $\beta$ heme pocket (black, PDB 2DN2). This model of $\mathrm{Hb}$ Zurich is based on the structures solved by Phillips et al. (1981) and Tucker et al. (1978). It was generated with the macromolecular modeling program Coot (Emsley et al. 2010) by mutating the distal His of deoxy- $\beta$ (PDB 2DN2) to Arg. The distal Arg E7 (red) is oriented toward the CD corner, disturbing the position of Phe CD1 and Phe CD4 (orange). The heme pocket entrance is much wider allowing increased access to ligands. However, unlike normal His E7, mutant Arg is unable to stabilize bound $\mathrm{O}_{2}$ via hydrogen bonding. $(B)$ Stereo diagram showing the structural changes associated with substitution of $\beta$ Val E11. The wild-type structure carrying the branched hydrophobic side chain Val (black bonds, PDB 2DN2) is overlaid with structures carrying the largest aromatic side chain Trp E11 (orange, PDB 101K) or a polar side chain Thr E11 (green PDB, 1HDB). It is clear that no major backbone or side chain repacking occurs. Thus, mutations in this position are likely to have specific effects in changing the volume of the heme pocket accessible to solvent or diatomic ligands and the electrostatic properties of the pocket. These changes will manifest as differences in $\mathrm{O}_{2}$ binding, ligand selectivity, autoxidation, and heme loss. 
$(\beta 6[\mathrm{~A} 3] \mathrm{Glu}>\mathrm{Val}$ and $\beta 68[\mathrm{E} 12]$ Leu $>$ Phe $)$ contains two defects in the same $\beta$ chain, a $\beta 6$ Glu to Val substitution that causes sickle cell anemia (Serjeant and Rodgers 2012) and a $\beta 68$ amino acid substitution that reduces $\mathrm{O}_{2}$ affinity, probably by destabilizing the oxygenated conformation through steric effects introduced into helix E (Geva et al. 2004). The affected patient, who was heterozygous for the mutant allele, showed symptoms of sickle cell anemia that were precipitated by infection or airplane travel. Thus, an amino acid substitution that reduces $\mathrm{O}_{2}$ affinity exacerbates the effects of a sickling mutation in the same globin chain.

Several other $\mathrm{Hb}$ variants modulate the severity of sickle cell anemia ( see also Cao and Kan 2012; Schechter and Elion 2012; Serjeant and Rodgers 2012). For example, $\gamma$ globin inhibits polymerization of HbS (Nagel et al. 1979). This effect is attributable to differences in several amino acid residues compared with the corresponding $\beta$ chain, including $\gamma 80$ and $\gamma 87$ (Adachi and Asakura 1979; Nagel et al. 1979; Adachi et al. 1996). Hb D-Ibadan ( $\beta 87$ [F3] Thr > Lys), which introduces a lysine residue at the $\beta 87$ position, is presumed to have decreased interaction with the mutant Val residue at HbS $\beta 6$ (WatsonWilliams et al. 1965; Nagel et al. 1979). Thus, Hb D-Ibadan inhibits HbS polymerization. In contrast, Hb Quebec-Chori ( $\beta 87$ [F3] Thr > Ile) was identified in a compound heterozygous patient with mild to moderately severe sickle cell anemia (Witkowska et al. 1991). The introduction of an isoleucine at $\beta 87$ causes Hb QuebecChori to promote deoxygenated HbS polymerization.

Hb Bristol-Alesha ( $\beta 67$ [E11] Val > Met) (Molchanova et al. 1993; Rees et al. 1996) and Hb Toms River $(\gamma 67$ [E11] Val $>$ Met) (Crowley et al. 2011), which contain analogous amino acid substitutions in $\beta$ and $\gamma$ chains, respectively, represent interesting globin variants with multiple biochemical defects. Hb Bristol-Alesha was initially observed in patients with moderately severe hemolytic anemia. Studies of the mutant protein in patient erythrocytes revealed a $\beta 67$ Val $>$ Asp substitution, predicted to render the protein unstable by introducing a highly charged polar residue into the hydrophobic heme pocket. However, subsequent DNA analysis of the same patient identified a Val $>$ Met codon substitution (Rees et al. 1996). The investigators concluded that the mutant Met residue was converted to Asp posttranslationally, probably through oxidative mechanisms. More recently, the analogous variant was identified in fetal $(\gamma)$ globin ( $\mathrm{Hb}$ Toms River) (Crowley et al. 2011). The affected patient was a newborn presenting with both cyanosis and anemia. DNA testing revealed the codon change ( Val $>$ Met at E11). Mass spectrometry of patient hemolysate indicated a mixture of variant $\gamma$ globins containing either Met or Asp at position E11. Although no structural studies have been performed with $\mathrm{Hb}$ chains carrying Met or Asp E11, structures with polar (Thr) or large aromatic (Trp) substitutions are available. These indicate that a range of amino acids can be accommodated without gross changes in the heme pocket structure (Fig. 5B). Instead, altered steric and electrostatic interactions with the distal His and diatomic ligands entering the heme pocket are likely to be functionally significant. Biochemical studies indicated that the $\mathrm{Hb}$ Toms River Met substitution produced a stable, low $\mathrm{O}_{2}$ affinity variant $\gamma$ globin, causing cyanosis. Its gradual posttranslational conversion to Asp destabilized the molecule, causing hemolytic anemia. This provides an example of how posttranslational modifications of variant globins can modify phenotypes. The reason that $\mathrm{Hb}$ Bristol-Alesha causes predominantly hemolytic anemia whereas $\mathrm{Hb}$ Toms River causes mainly cyanosis probably reflects different rates of Met conversion to Asp in the variant globin chains.

\section{CONCLUDING REMARKS}

More than $1000 \mathrm{Hb}$ variants are known to exist (Globin Gene Server; Hardison et al. 2002; Giardine et al. 2011). These are mainly missense mutations that destabilize $\mathrm{Hb}$, alter $\mathrm{Hb}-\mathrm{O}_{2}$ affinity, or most commonly, alter $\mathrm{Hb}$ function minimally. Moreover, variants that do alter $\mathrm{Hb}$ biochemistry are rarely life threatening or health compromising. Nonetheless, studies of these variants have been of great benefit to science and medicine for two main reasons. First, 


\section{C.S. Thom et al.}

identification of $\mathrm{Hb}$ gene mutations as a cause for cyanosis, erythrocytosis, or mild hemolysis in otherwise healthy patients provides reassurance and minimizes additional diagnostic procedures, sparing expense and risk. Second, efforts to understand how $\mathrm{Hb}$ variants produce their structural, biochemical, and clinical effects has generated important insights into red blood cell function and also created general paradigms for the study of protein biology. Despite hundreds of studies over more than 50 years, new $\mathrm{Hb}$ variants continue to emerge, yielding new insights into this important molecule.

\section{ACKNOWLEDGMENTS}

We thank Drs. Franklin Bunn, Kazuhiko Adachi, and John Olson for comments on the manuscript. Hemoglobin research in Dr. Weiss's laboratory is funded through National Institutes of Health (NIH) grants DK061692, HL087427, and P30DK090969. The authors declare no competing financial interests.

\section{REFERENCES}

* Reference is also in this collection.

Adachi K, Asakura T. 1979. The solubility of sickle and nonsickle hemoglobins in concentrated phosphate buffer. J. Biol Chem 254: 4079-4084.

Adachi K, Pang J, Konitzer P, Surrey S. 1996. Polymerization of recombinant hemoglobin $\mathrm{F} \gamma \mathrm{E} 6 \mathrm{~V}$ and hemoglobin $\mathrm{F}$ $\gamma \mathrm{E} 6 \mathrm{~V}, \gamma \mathrm{Q} 87 \mathrm{~T}$ alone, and in mixtures with hemoglobin S. Blood 87: 1617-1624.

Adachi K, Surrey S, Nagai M. 2011. Hemoglobinopathies due to amino acid mutation/deletion: HbS and HbM. In Hemoglobin: Recent developments and topics, pp. 179-210. Research Signpost, Kerala, India.

Adams J, Boxer L, Baehner R, Forget B, Tsistrakis G, Steinberg M. 1979. Hemoglobin Indianapolis ( $\beta 112$ [G14] arginine). An unstable $\beta$-chain variant producing the phenotype of severe $\beta$-thalassemia. J Clin Invest 63: 931-938.

Ameri A, Fairbanks V, Yanik G, Mahdi F, Thibodeau S, McCormick D, Boxer L, McDonagh K. 1999. Identification of the molecular genetic defect of patients with methemoglobin M-Kankakee (M-Iwate), $\alpha 87$ (F8) His $\rightarrow$ Tyr: Evidence for an electrostatic model of $\alpha \mathrm{M}$ hemoglobin assembly. Blood 94: 1825-1826.

Argos P, Rossman MG, Grau UM, Zuber H, Frank G, Tratschin JD. 1979. Thermal stability and protein structure. Biochemistry 18: 5698-5703.

Arnone A. 1972. X-ray diffraction study of binding of 2,3diphosphoglycerate to human deoxyhaemoglobin. $\mathrm{Na}$ ture 237: 146-149.
Arous N, Braconnier F, Thillet J, Blouquit Y, Galacteros F, Chevrier M, Bordahandy C, Rosa J. 1981. Hemoglobin Saint Mandé $[\beta 102$ (G4) Asn $\rightarrow$ Tyr]: A new low oxygen affinity variant. FEBS Lett 126: 114-116.

Asakura T, Adachi K, Shapiro M, Friedman S, Schwartz E. 1975. Mechanical precipitation of hemoglobin köln. Biochim Biophys Acta 412: 197-201.

Bachmann F, Marti HR. 1962. Hemoglobin Zürich. II. Physicochemical properties of the abnormal hemoglobin. Blood 20: 272-86.

Bare GH, Bromberg PA, Alben JO, Brimhall B, Jones RT, Mintz S, Rother I. 1976. Altered C-terminal salt bridges in haemoglobin York cause high oxygen affinity. Nature 259: 155-156.

Bender JW, Adachi K, Asakura T. 1981. Precipitation of oxyhemoglobins A and S by isopropanol. Hemoglobin 5: 463-474.

Blouquit Y, Bardakdjian J, Lena-Russo D, Arous N, Perrimond H, Orsini A, Rosa J, Galacteros F. 1989. Hb Bruxelles: $\alpha$ 2A $\beta$ (2)41 or 42(C7 or CD1)Phe deleted. Hemoglobin 13: 465-474.

Bonaventura J, Riggs A. 1968. Hemoglobin Kansas, a human hemoglobin with a neutral amino acid substitution and an abnormal oxygen equilibrium. J. Biol Chem 243: 980991.

Bonaventura J, Bonaventura C, Sullivan B, Ferruzzi G, McCurdy PR, Fox J, Moo-Penn WF. 1976. Hemoglobin providence. Functional consequences of two alterations of the 2,3-diphosphoglycerate binding site at position $\beta 82$. J. Biol Chem 251: 7563-7571.

Bratu V, Lorkin PA, Lehmann H, Predescu C. 1971. Haemoglobin Buccureşti 42(CD1) Phe-Leu, a cause of unstable haemoglobin haemolytic anaemia. Biochim Biophys Acta 251: $1-6$.

Bunn HF, Forget BG. 1986. Hemoglobin: Molecular, genetic and clinical aspects. W.B. Saunders, Philadelphia.

Bunn HF, Wohl RC, Bradley TB, Cooley M, Gibson QH. 1974. Functional properties of hemoglobin Kempsey. J Biol Chem 249: 7402-7409.

Bunn HF, Schmidt GJ, Haney DN, Dluhy RG. 1975. Hemoglobin Cranston, an unstable variant having an elongated $\beta$ chain due to nonhomologous crossover between two normal $\beta$ chain genes. Proc Natl Acad Sci 72: 3609-3613.

* Cao A, Kan YW. 2012. The prevention of thalassemia. Cold Spring Harb Perspect Med doi: 10.1101/cshperspect. a011775.

Carrell RW, Kay R. 1972. A simple method for the detection of unstable haemoglobins. Br J Haematol 23: 615-619.

Charache S, Fox J, McCurdy P, Kazazian H Jr, Winslow R, Hathaway P, van Beneden R, Jessop M. 1977. Postsynthetic deamidation of hemoglobin Providence ( $\beta 82$ Lys replaced by Asn, Asp) and its effect on oxygen transport. J. Clin Invest 59: 652-658.

Clegg JB, Weatherall DJ. 1974. Hemoglobin Constant Spring, and unusual $\alpha$-chain variant involved in the etiology of hemoglobin $\mathrm{H}$ disease. Ann NY Acad Sci 232: $168-178$.

Clegg J, Weatherall D, Boon W, Mustafa D. 1969. Two new haemoglobin variants involving proline substitutions. Nature 222: 379-380. 
Hemoglobin Variants

Clegg JB, Weatherall DJ, Milner PF. 1971. Haemoglobin Constant Spring-A chain termination mutant? Nature 234: $337-340$.

Coleman MB, Steinberg MH, Adams JG 3rd. 1991. Hemoglobin Terre Haute arginine $\beta 106$. A posthumous correction to the original structure of hemoglobin Indianapolis. J Biol Chem 266: 5798-5800.

Como PF, Wylie BR, Trent RJ, Bruce D, Volpato F, Wilkinson T, Kronenberg H, Holland RA, Tibben EA. 1991. A new unstable and low oxygen affinity hemoglobin variant: $\mathrm{Hb}$ Stanmore ( $\beta 111$ [G13] Val $\rightarrow$ Ala). Hemoglobin 15: 53-65.

Crowley M, Mollan T, Abdulmalik O, Butler AD, Goodwin E, Sarkar A, Stolle C, Gow A, Olson J, Weiss M. 2011. A hemoglobin variant associated with neonatal cyanosis and anemia. N Engl J Med 364: 1837-1843.

Dacie JV, Shinton NK, Gaffney PJ Jr, Lehmann H. 1967. Haemoglobin Hammersmith ( $\beta-42$ [CDI] Phe replaced by ser). Nature 216: 663-665.

* Dailey HA, Meissner PN. 2012. Erythroid heme biosynthesis and its disorders. Cold Spring Harb Perspect Med doi: 10.1101/cshperspect.a011676.

Derry S, Wood WG, Pippard M, Clegg JB, Weatherall DJ, Wickramasinghe SN, Darley J, Fucharoen S, Wasi P. 1984 Hematologic and biosynthetic studies in homozygous hemoglobin Constant Spring. J. Clin Invest 73: 16731682.

Efremov GD, Wrightstone RN, Huisman TH, Schroeder WA, Hyman C, Ortega J, Williams K. 1971. An unusual hemoglobin anomaly and its relation to $\alpha$-thalassemia and hemoglobin-H disease. J. Clin Invest 50: 1628-1636.

Eisinger J, Flores J, Tyson JA, Shohet SB. 1985. Fluorescent cytoplasm and Heinz bodies of hemoglobin Köln erythrocytes: Evidence for intracellular heme catabolism. Blood 65: 886-893.

Emsley P, Lohkamp B, Scott WG, Cowtan K. 2010. Features and development of Coot. Acta Cryst 66: 486-501.

Favero ME, Costa FF. 2011. $\alpha$-Hemoglobin-stabilizing protein: An erythroid molecular chaperone. Biochem Res Int 2011: 373859 .

Forget BG, Marotta CA, Weissman SM, Cohen-Solal M. 1975. Nucleotide sequences of the $3^{\prime}$-terminal untranslated region of messenger RNA for human $\beta$ globin chain. Proc Natl Acad Sci 72: 3614-3618.

Frick PG, Hitzig WH, Betke K. 1962. Hemoglobin Zurich. I. A new hemoglobin anomaly associated with acute hemolytic episodes with inclusion bodies after sulfonamide therapy. Blood 20: 261-271.

Frischer H, Bowman J. 1975. Hemoglobin E, an oxidatively unstable mutation. J Lab Clin Med 85: 531-539.

* Ganz T, Nemeth E. 2012. Iron metabolism: Interactions with normal and disordered erythropoiesis. Cold Spring Harb Perspect Med doi: $10.1101 /$ cshperspect.a011668.

Garrod A. 1928. The lessons of rare maladies: Annual oration before the medical society of London. Lancet 1: 914-915.

Geva A, Clark JJ, Zhang Y, Popowicz A, Manning JM, Neufeld EJ. 2004. Hemoglobin Jamaica Plain—A sickling hemoglobin with reduced oxygen affinity. $N$ Engl J Med 351: $1532-1538$.
Giardine B, Borg J, Higgs D, Peterson K, Philipsen S, Maglott D, Singleton B, Anstee D, Basak A, Clark B, et al. 2011. Systematic documentation and analysis of human genetic variation in hemoglobinopathies using the microattribution approach. Nat Genet 43: 295-301.

Gibson QH, Riggs A, Imamura T. 1973. Kinetic and equilibrium properties of hemoglobin Kansas. J. Biol Chem 248: 5976-5986.

Giordano PC, Zweegman S, Akkermans N, Arkesteijn SGJ, van Delft Peter, Versteegh FGA, Wajcman Henri, Harteveld CL. 2007. The first case of $\mathrm{Hb}$ Groene Hart $(\alpha 119[\mathrm{H} 2]$ Pro $\rightarrow$ Ser, CCT $\rightarrow$ TCT $[\alpha 1])$ homozygosity confirms that a thalassemia phenotype is associated with this abnormal hemoglobin variant. Hemoglobin 31: 179-182.

Griffon N, Badens C, Lena-Russo D, Kister J, Bardakdjian J, Wajcman H, Marden MC, Poyart C. 1996. Hb Bruxelles, deletion of $\mathrm{Phe}^{\beta 42}$, shows a low oxygen affinity and low cooperativity of ligand binding. J. Biol Chem 271: 25916-25920.

Hamilton HB, Iuchi I, Miyaji T, Shibata S. 1969. Hemoglobin Hiroshima $\left(\beta^{143}\right.$ histidine $\rightarrow$ aspartic acid): A newly identified fast moving $\beta$ chain variant associated with increased oxygen affinity and compensatory erythremia. J. Clin Invest 48: 525-535.

Hardison R, Chui D, Giardine B, Riemer C, Patrinos G, Anagnou N, Miller W, Wajcman H. 2002. HbVar: A relational database of human hemoglobin variants and thalassemia mutations at the globin gene server. Hum Mutat 19: $225-233$.

Harteveld C, van Delft P, Plug R, Versteegh F, Hagen B, van Rooijen I, Kok P, Wajcman H, Kister J, Giordano PC. 2002. Hb Groene Hart: A new Pro $\rightarrow$ Ser amino acid substitution at position 119 of the $\alpha 1$-globin chain is associated with a mild $\alpha$-thalassemia phenotype. Hemoglobin 26: $255-60$.

Hayashi A, Shimizu A, Yamamura Y, Watari H. 1966. Hemoglobins M: Identification of Iwate, Boston, and Saskatoon variants. Science 152: 207-208.

Hebbel RP, Eaton JW, Kronenberg RS, Zanjani ED, Moore LG, Berger EM. 1978. Human llamas: Adaptation to altitude in subjects with high hemoglobin oxygen affinity. J Clin Invest 62: 593-600.

Honig GR, Vida LN, Rosenblum BB, Perutz MF, Fermi G. 1990. Hemoglobin Warsaw $\left(\mathrm{Phe}^{\beta 42(\mathrm{CD} 1)} \rightarrow\right.$ Val), an unstable variant with decreased oxygen affinity. Characterization of its synthesis, functional properties, and structure. J. Biol Chem 265: 126-132.

Horlein H, Weber G. 1948. Ueber chronische familiäre methämoglobinämie und eine neue modifikation des methämoglobins. Dtsch Med Wochenschr 73: 476-478.

Hoyer JD, McCormick DJ, Snow K, Kwon JH, Booth D, Duarte M, Grayson G, Kubik KS, Holmes MW, Fairbanks VF. 2002. Four new variants of the $\alpha 2$-globin gene without clinical or hematologic effects: $\mathrm{Hb}$ Park Ridge $(\alpha 9[\alpha 7]$ Asn $\rightarrow$ Lys $[\alpha 2])$, Hb Norton $(\alpha 72[\mathrm{EF} 1]$ His $\rightarrow$ Asp $[\alpha 2]), \mathrm{Hb}$ Lombard $(\alpha 103[$ G10]His $\rightarrow$ Tyr $[\alpha 2]$ ), and $\mathrm{Hb}$ San Antonio (A113[GH2]Leu $\rightarrow$ Arg [A2]). Hemoglobin 26: 175-179.

Huisman TH. 1997. Hb E and $\alpha$-thalassemia; variability in the assembly of $\beta^{\mathrm{E}}$ chain containing tetramers. Hemoglobin 21: $227-236$. 


\section{C.S. Thom et al.}

Huisman TH, Horton B, Bridges MT, Betke K, Hitzig WH 1961. A new abnormal human hemoglobin-Hb: Zurich. Clin Chim Acta 6: 347-355.

Hunt DM, Higgs DR, Winichagoon P, Clegg JB, Weatherall DJ. 1982. Haemoglobin Constant Spring has an unstable $\alpha$ chain messenger RNA. Br J Haematol 51: 405413.

Ikkala E, Koskela J, Pikkarainen P, Rahiala EL, El-Hazmi MA, Nagai K, Lang A, Lehmann H. 1976. Hb Helsinki: Avariant with a high oxygen affinity and a substitution at a 2,3-DPG binding site ( $\beta 82$ [EF6] Lys replaced by Met). Acta Haematol 56: 257-275.

Imai K, Hamilton HB, Miyaji T, Shibata S. 1972. Physicochemical studies of the relation between structure and function in hemoglobin Hiroshima (HC3, histidine leads to aspartate). Biochemistry 11: 114-121.

Jin Y, Nagai M, Nagai Y, Nagatomo S, Kitagawa T. 2004 Heme structures of five variants of hemoglobin M probed by resonance Raman spectroscopy. Biochemistry 43: 8517-8527.

Keeling MM, Ogden LL, Wrightstone RN, Wilson JB, Reynolds CA, Kitchens JL, Huisman TH. 1971. Hemoglobin Louisville ( $\beta-42$ [CD1] phe-leu): An unstable variant causing mild hemolytic anemia. J Clin Invest 50: 2395-2402.

Khandros E, Mollan TL, Yu X, Wang X, Yao Y, D'Souza J, Gell DA, Olson JS, Weiss MJ. 2012. Insights into hemoglobin assembly through in vivo mutagenesis of $\alpha$-hemoglobin stabilizing protein. J Biol Chem 287: 11325-11327.

King MA, Wiltshire BG, Lehmann H, Morimoto H. 1972. An unstable haemoglobin with reduced oxygen affinity: Haemoglobin Peterborough, 3 (GI3) Valine lead to Phenylalanine, its interaction with normal haemoglobin and with haemoglobin Lepore. Br J Haematol 22: 125-134.

Kohne E. 2011. Hemoglobinopathies: Clinical manifestations, diagnosis, and treatment. Dtsch Ärztebl Int 108: 532.

Konigsberg W, Lehmann H. 1965. The amino acid substitution in hemoglobin M-Iwate. Biochim Biophys Acta 107: 266-269.

Konigsberg W, Guidotti G, Hill RJ. 1961. The amino acid sequence of the $\alpha$ chain of human hemoglobin. J. Biol Chem 236: PC55-PC56.

Lacan P, Aubry M, Couprie N, Francina A. 2004. Two new a chain variants: $\mathrm{Hb}$ Die $(\alpha 93$ [FG5] Val $\rightarrow$ Ala $[\alpha 1])$ and Hb Beziers $(\alpha 99[$ G6]Lys $\rightarrow$ Asn $[\alpha 1])$. Hemoglobin 28: 59-63.

Lacerra G, Scarano C, Musollino G, Flagiello A, Pucci P, Carestia C. 2008. Hb Foggia or $\alpha 117$ (GH5)Phe $\rightarrow$ Ser: A new $\alpha 2$ globin allele affecting the $\alpha \mathrm{Hb}$-AHSP interaction. Haematologica 93: 141-142.

Lal A, Goldrich ML, Haines DA, Azimi M, Singer ST, Vichinsky EP. 2011. Heterogeneity of hemoglobin H disease in childhood. N. Engl J Med 364: 710-718.

Langdown JV, Davidson RJ, Williamson D. 1992. A new $\alpha$ chain variant, Hb Turriff $(\alpha 99$ [G6] Lys $\rightarrow$ Glu $):$ The interference of abnormal hemoglobins in Hb Alc determination. Hemoglobin 16: 11-17.

Lehmann H. 1957. Haemoglobin and its abnormalities. Practitioner 178: 198-214.
* Lettre G. 2012. The search for genetic modifiers of disease severity in the $\beta$-hemoglobinopathies. Cold Spring Harb Perspect Med doi: 10.1101/cshperspect.a015032.

Levitt M. 1981. Effect of proline residues on protein folding. J. Mol Biol 145: 251-263.

Lindstrom TR, Baldassare JJ, Bunn HF, Ho C. 1973. Nuclear magnetic resonance and spin-label studies of hemoglobin Kempsey. Biochemistry 12: 4212-4217.

Little R, Roberts W. 2009. A review of variant hemoglobins interfering with hemoglobin Alc measurement. J Diabetes Sci Technol 3: 446-451.

Lorkin P, Stephens A, Beard M, Wrigley P, Adams L, Lehmann H. 1975. Haemoglobin Rahere ( $\beta$ Lys-Thr): A new high affinity haemoglobin associated with decreased 2,3diphosphoglycerate binding and relative polycythaemia. Br Med J 4: 200-202.

Marinucci M, Mavilio F, Massa A, Gabbianelli M, Fontanarosa PP, Camagna A, Ignesti C, Tentori L. 1979. A new abnormal human hemoglobin: Hb Prato ( $\alpha 231$ [B12] Arg leads to Ser $\beta 2$ ). Biochim Biophys Acta 578: 534-540.

Martínez G, Lima F, Colombo B. 1977. Haemoglobin J

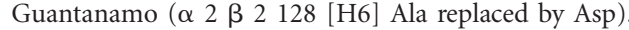
A new fast unstable haemoglobin found in a Cuban family. Biochim Biophys Acta 491: 1-6.

McDonald MJ, Lund DP, Bleichman M, Bunn HF, De Young A, Noble RW, Foster B, Arnone A. 1980. Equilibrium, kinetic and structural properties of hemoglobin Cranston, an elongated $\beta$ chain variant. J. Mol Biol 140: 357-375.

Milner PF, Clegg JB, Weatherall DJ. 1971. Haemoglobin-H disease due to a unique haemoglobin variant with an elongated $\alpha$-chain. Lancet 1: 729-732.

Molchanova TP, Postnikov YuV, Pobedimskaya DD, Smetanina NS, Moschan AA, Kazanetz EG, Tokarev YuN, Huisman TH. 1993. Hb Alesha or $\alpha 2 \beta$ (2)67 (E11)Val $\rightarrow$ Met: A new unstable hemoglobin variant identified through sequencing of amplified DNA. Hemoglobin 17: 217-225.

Mollan TL, Khandros E, Weiss MJ, Olson JS. 2012. The kinetics of $\alpha$-globin binding to $\alpha$ hemoglobin stabilizing protein (AHSP) indicate preferential stabilization of a hemichrome folding intermediate. J Biol Chem 287: $11338-11350$

Moo-Penn WF, Jue DL, Bechtel KC, Johnson MH, Schmidt RM. 1976. Hemoglobin Providence. A human hemoglobin variant occurring in two forms in vivo. J. Biol Chem 251: 7557-7562.

Moo-Penn W, Jue D, Johnson M, Olsen K, Shih D, Jones R, Lux S, Rodgers P, Arnone A. 1988. Hemoglobin Brockton $(\beta 138$ [H16] Ala $\rightarrow$ Pro): An unstable variant near the Cterminus of the $\beta$-subunits with normal oxygen-binding properties. Biochemistry 27: 7614-7619.

Morales J, Russell JE, Liebhaber SA. 1997. Destabilization of human $\alpha$-globin mRNA by translation anti-termination is controlled during erythroid differentiation and is paralleled by phased shortening of the poly(A) tail. J Biol Chem 272: 6607-6613.

* Musallam KM, Taher AT, Rachmilewitz EA. 2012. $\beta$-Thalassemia intermedia: A clinical perspective. Cold Spring Harb Perspect Med doi: 10.1101/cshperspect.a013482. 
Nagai M, Aki M, Li R, Jin Y, Sakai H, Nagatomo S, Kitagawa T. 2000. Heme structure of hemoglobin M Iwate $(\alpha 87[\mathrm{~F} 8] \mathrm{His} \rightarrow \mathrm{Tyr}): \mathrm{A}$ UV and visible resonance Raman study. Biochemistry 39: 13093-13105.

Nagel RL, Lynfield J, Johnson J, Landau L, Bookchin RM, Harris MB. 1976. Hemoglobin Beth Israel. A mutant causing clinically apparent cyanosis. N. Engl J Med 295: $125-130$.

Nagel RL, Bookchin RM, Johnson J, Labie D, Wajcman H, Isaac-Sodeye WA, Honig GR, Schilirò G, Crookston JH, Matsutomo K. 1979. Structural bases of the inhibitory effects of hemoglobin $\mathrm{F}$ and hemoglobin A2 on the polymerization of hemoglobin S. Proc Natl Acad Sci 76: 670-672.

Nathan D, Orkin S, Ginsburg D, Look A, Fisher D, Lux S. 2009. Nathan and Oski's hematology of infancy and childhood, 7th ed. Saunders Elsevier, Philadelphia.

Ohba Y, Miyaji T, Matsuoka M, Yokoyama M, Numakura H. 1975. Hemoglobin Hirosaki ( $\alpha 43$ [CE 1] Phe replaced by Leu), a new unstable variant. Biochim Biophys Acta 405: $155-160$.

Olson J, Gibson Q, Nagel R, Hamilton H. 1972. The ligand-binding properties of hemoglobin Hiroshima $\left(\alpha_{2} \beta_{2}^{146}\right.$ asp $)$. J Biol Chem 247: 7485-7493.

Orkin S, Kazazian HJ, Antonarakis S, Ostrer H, Goff S, Sexton J. 1982. Abnormal RNA processing due to the exon mutation of $\beta^{\mathrm{E}}$-globin gene. Nature 300: 768-769.

Paoli M, Liddington R, Tame J, Wilkinson A, Dodson G. 1996. Crystal structure of T state haemoglobin with oxygen bound at all four haems. J Mol Biol 256: 775-792.

Park S, Yokoyama T, Shibayama N, Shiro Y, Tame JR. 2006. 1.25 A resolution crystal structures of human haemoglobin in the oxy, deoxy and carbonmonoxy forms. J Mol Biol 360: 690-701.

Perutz M. 1960. Structure of hemoglobin. Brookhaven Symp Biol 13: $165-183$.

Perutz M. 1970. Stereochemistry of cooperative effects in haemoglobin. Nature 228: 726-739.

Perutz M, Lehmann H. 1968. Molecular pathology of human haemoglobin. Nature 219: 902-909.

Perutz M, Rossman M, Cullis A, Muirhead H, Will G, North A. 1960. Structure of haemoglobin: Three-dimensional Fourier synthesis at 5.5-A resolution, obtained by X-ray analysis. Nature 185: 416-422.

Perutz MF, Muirhead H, Mazzarella L, Crowther RA, Greer J, Kilmartin JV. 1969. Identification of residues responsible for the alkaline Bohr effect in haemoglobin. Nature 222: $1240-1243$.

Perutz MF, Pulsinelli P, Eyck LT, Kilmartin JV, Shibata S, Iuchi I, Miyaji T, Hamilton HB. 1971. Haemoglobin Hiroshima and the mechanism of the alkaline Bohr effect. Nat New Biol 232: 147-149.

Perutz M, Fermi G, Shih TB. 1984. Structure of deoxyhemoglobin Cowtown (His HC3 [146] $\beta \rightarrow$ Leu): Origin of the alkaline Bohr effect and electrostatic interactions in hemoglobin. Proc Natl Acad Sci 81: 4781-4784.

Phillips SE, Hall D, Perutz MF. 1981. Structure of deoxyhaemoglobin Zürich (HisE7 [63 $\beta]$ —greater than Arg). J Mol Biol 150: 137-141.

Poyart C, Schaad O, Kister J, Galacteros F, Edelstein SJ, Blouquit Y, Arous N. 1990. Hemoglobin Saint Mandé $[\beta 102(G 4)$ Asn $\rightarrow$ Tyr]. Functional studies and structural modeling reveal an altered T state. Eur J Biochem 194: 343-348.

Pulsinelli PD, Perutz M, Nagel R. 1973. Structure of hemoglobin M Boston, a variant with a five-coordinated ferric heme. Proc Natl Acad Sci 70: 3870-3874.

Rabbitts TH. 1976. Bacterial cloning of plasmids carrying copies of rabbit globin messenger RNA. Nature 260: 221-225.

Reed CS, Hampson R, Gordon S, Jones RT, Novy MJ, Brimhall B, Edwards MJ, Koler RD. 1968. Erythrocytosis secondary to increased oxygen affinity of a mutant hemoglobin, hemoglobin Kempsey. Blood 31: 623-632.

Rees DC, Rochette J, Schofield C, Green B, Morris M, Parker NE, Sasaki H, Tanaka A, Ohba Y, Clegg JB. 1996. A novel silent posttranslational mechanism converts methionine to aspartate in hemoglobin Bristol ( $\beta 67$ [E11] Val-Met $\rightarrow$ Asp). Blood 88: 341-348.

Rees DC, Clegg JB, Weatherall DJ. 1998. Is hemoglobin instability important in the interaction between hemoglobin $\mathrm{E}$ and $\beta$ thalassemia? Blood 92: 2141-2146.

Reissmann K, Ruth W, Nomura T. 1961. A human hemoglobin with lowered oxygen affinity and impaired hemeheme interactions. J Clin Invest 40: 1826-1833.

Rieder RF, Oski FA, Clegg JB. 1969. Hemoglobin Philly ( $\beta 35$ tyrosine phenylalanine): Studies in the molecular pathology of hemoglobin. J. Clin Invest 48: 1627-1642.

Riggs A, Gibson QH. 1973. Oxygen equilibrium and kinetics of isolated subunits from hemoglobin Kansas. Proc Natl Acad Sci 70: 1718-1720.

Roth EF Jr, Elbaum D, Bookchin RM, Nagel RL. 1976. The conformational requirements for the mechanical precipitation of hemoglobin S and other mutants. Blood 48: 265-271.

Russu IM, Ho C. 1986. Assessment of role of $\beta$ 146-histidyl and other histidyl residues in the Bohr effect of human normal adult hemoglobin. Biochemistry 25: 1706-1716.

* Sankaran VG, Orkin SH. 2012. The switch from fetal to adult hemoglobin. Cold Spring Harb Perspect Med doi: 10.1101/cshperspect.a011643.

Schneider RG, Bremner JE, Brimhall B, Jones RT, Shih TB. 1979. Hemoglobin Cowtown ( $\beta 146$ HC3 His-Leu): A mutant with high oxygen affinity and erythrocytosis. Am J Clin Pathol 72: 1028-1032.

Schrier SL, Bunyaratvej A, Khuhapinant A, Fucharoen S, Aljurf M, Snyder LM, Keifer CR, Ma L, Mohandas N. 1997. The unusual pathobiology of hemoglobin constant spring red blood cells. Blood 89: 1762-1769.

Schroeder WA, Jones RT, Shelton JR, Shelton JB, Cormick J, McCalla K. 1961. A partial sequence of the amino acid residues in the $\gamma$ chain of human hemoglobin F. Proc Natl Acad Sci 47: 811-818.

Sciarratta GV, Ivaldi G, Molaro GL, Sansone G, Salkie ML, Wilson JB, Reese AL, Huisman TH. 1984. The characterization of hemoglobin Manitoba or $\alpha_{2}$ 102(G9)Ser $\rightarrow$ Arg $\beta_{2}$ and hemoglobin Contaldo or $\alpha_{2} 103(\mathrm{G} 10) \mathrm{His} \rightarrow$ Arg $\beta_{2}$ by high performance liquid chromatography. Hemoglobin 8: 169-181.

Shaeffer JR, Schmidt GJ, Kingston RE, Bunn HF. 1980. Synthesis of hemoglobin Cranston, and elongated $\beta$ chain variant. J Mol Biol 140: 377-389. 


\section{C.S. Thom et al.}

* Schechter A. 2012. Hemoglobin function. Cold Spring Harb Perspect Med doi: 10.1101/cshperspect.a011650.

* Schechter A, Elion J. 2012. Cold Spring Harb Perspect Med (to be published).

* Serjeant G, Rodgers G. 2012. Natural history of sickle cell disease. Cold Spring Harb Perspect Med doi: 10.1101/ cshperspect.a011783.

Shibata S, Tanuira A, Iuchi I. 1960. Hemoglobin M1 demonstration of a new abnormal hemoglobin in hereditary nigremia. Acta Haematol Jpn 23: 96-105.

Shimizu A, Tsugita A, Hayashi A, Yamamura Y. 1965. The primary structure of hemoglobin M-Iwate. Biochim Biophys Acta 107: 270-277.

Springer BA, Egeberg KD, Sligar SG, Rohlfs RJ, Mathews AJ, Olson JS. 1989. Discrimination between oxygen and carbon monoxide and inhibition of autooxidation by myoglobin. Site-directed mutagenesis of the distal histidine. $J$ Biol Chem 264: 3057-3060.

Stamatoyannopoulos G, Parer JT, Finch CA. 1969. Physiologic implications of a hemoglobin with decreased oxygen affinity (hemoglobin seattle). $N$ Engl $J$ Med 281: 916-919.

Stamatoyannopoulos G, Woodson R, Papayannopoulou T, Heywood D, Kurachi S. 1974. Inclusion-body $\beta$-thalassemia trait. A form of $\beta$ thalassemia producing clinical manifestations in simple heterozygotes. $N$ Engl J Med 290: 939-943.

Steinberg M, Forget B, Higgs D, Nagel R. 2001. Disorders of hemoglobin: Genetics, pathophysiology, and clinical management. Cambridge University Press, Cambridge.

Sugihara J, Imamura T, Nagafuchi S, Bonaventura J, Bonaventura C, Cashon R. 1985. Hemoglobin Rahere, a human hemoglobin variant with amino acid substitution at the 2,3-diphosphoglycerate binding site. Functional consequences of the alteration and effects of bezafibrate on the oxygen bindings. J Clin Invest 76: 1169-73.

Tanaka Y, Matsui K, Matsuda K, Shinohara K, Haranob K. 2005. A family with hemoglobin Hirosaki. Int J Hematol 82: $124-126$.

Thein SL, Hesketh C, Taylor P, Temperley IJ, Hutchinson RM, Old JM, Wood WG, Clegg JB, Weatherall DJ. 1990. Molecular basis for dominantly inherited inclusion body $\beta$-thalassemia. Proc Natl Acad Sci 87: 3924-3928.

Tremper K, Barker S. 1989. Pulse oximetry. Anesthesiology 70: $98-108$.

Tucker PW, Phillips SE, Perutz MF, Houtchens R, Caughey WS. 1978. Structure of hemoglobins Zürich (His E7 [63] $\beta$ replaced by Arg) and Sydney (Val E11[67] $\beta$ replaced by Ala) and role of the distal residues in ligand binding. Proc Natl Acad Sci 75: 1076-1080.

Turbpaiboon C, Limjindaporn T, Wongwiwat W, UPratya Y, Siritanaratkul N, Yenchitsomanus P-thai, Jitrapakdee S, Wilairat P. 2006. Impaired interaction of $\alpha$-haemoglobin-stabilising protein with $\alpha$-globin termination mutant in a yeast two-hybrid system. Br J Haematol 132: $370-373$.

Vasseur C, Domingues-Hamdi E, Brillet T, Marden Michael C, Baudin-Creuza V. 2009. The $\alpha$-hemoglobin stabilizing protein and expression of unstable $\alpha-\mathrm{Hb}$ variants. Clin Biochem 42: 1818-1823.

Vasseur-Godbillon C, Marden M, Giordano P, Wajcman H, Baudin-Creuza V. 2006. Impaired binding of AHSP to $\alpha$ chain variants: $\mathrm{Hb}$ Groene Hart illustrates a mechanism leading to unstable hemoglobins with $\alpha$ thalassemic like syndrome. Blood Cells Mol Dis 37: 173-179.

Verhovsek M, Henderson M, Cox G, Luo H, Steinberg M, Chui D. 2010. Unexpectedly low pulse oximetry measurements associated with variant hemoglobins: A systematic review. Am J Hematol 85: 882-885.

Viprakasit V, Tanphaichitr VS. 2002. Compound heterozygosity for $\alpha^{0}$-thalassemia (- -THAI) and $\mathrm{Hb}$ constant spring causes severe $\mathrm{Hb} \mathrm{H}$ disease. Hemoglobin 26: $155-162$.

Wajcman H, Moradkhani K. 2011. Abnormal haemoglobins: Detection and characterization. Indian J Med Res 134: $538-546$.

Wajcman H, Préhu C, Bardakdjian-Michau J, Promé D, Riou J, Godart C, Mathis M, Hurtrel D, Galactéros F. 2001. Abnormal hemoglobins: Laboratory methods. $\mathrm{He}$ moglobin 25: 169-181.

Wajcman H, Traeger-Synodinos J, Papassotiriou I, Giordano PC, Harteveld CL, Baudin-Creuza V, Old J. 2008. Unstable and thalassemic $\alpha$ chain hemoglobin variants: A cause of $\mathrm{Hb} \mathrm{H}$ disease and thalassemia intermedia. $\mathrm{He}$ moglobin 32: 327-349.

Watson HC, Kendrew JC. 1961. The amino-acid sequence of sperm whale myoglobin. Comparison between the amino-acid sequences of sperm whale myoglobin and of human hemoglobin. Nature 190: 670-672.

Watson-Williams EJ, Beale D, Irvine D, Lehmann H. 1965. A new haemoglobin, D-Ibadan ( $\beta-87$ threonine-lysine), producing no sickle-cell haemoglobin $\mathrm{D}$ disease with haemoglobin S. Nature 205: 1273-1276.

Weatherall D, Clegg J. 2001. Inherited haemoglobin disorders: An increasing global health problem. Bull World Health Organ 79: 704-712.

Weiss IM, Liebhaber SA. 1994. Erythroid cell-specific determinants of $\alpha$-globin mRNA stability. Mol Cell Biol 14: 8123-8132.

Weiss MJ, Zhou S, Feng L, Gell DA, Mackay JP, Shi Y, Gow AJ. 2005. Role of $\alpha$-hemoglobin-stabilizing protein in normal erythropoiesis and $\beta$-thalassemia. Ann NY Acad Sci 1054: 103-117.

* Williams TN, Weatherall DJ. 2012. World distribution, population genetics, and health burden of the hemoglobinopathies. Cold Spring Harb Perspect Med doi: 10.1101/ cshperspect.a011692.

Witkowska HE, Lubin BH, Beuzard Y, Baruchel S, Esseltine DW, Vichinsky EP, Kleman KM, BardakdjianMichau J, Pinkoski L, Cahn S. 1991. Sickle cell disease in a patient with sickle cell trait and compound heterozygosity for hemoglobin S and hemoglobin Quebec-Chori. $N$ Engl J Med 325: 1150-1154.

Yu X, Mollan TL, Butler Andrew, Gow AJ, Olson JS, Weiss MJ. 2009. Analysis of human $\alpha$ globin gene mutations that impair binding to the $\alpha$ hemoglobin stabilizing protein. Blood 113: 5961-5969. 


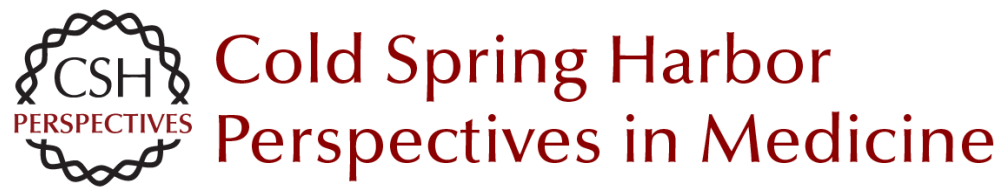

\section{Hemoglobin Variants: Biochemical Properties and Clinical Correlates}

Christopher S. Thom, Claire F. Dickson, David A. Gell and Mitchell J. Weiss

Cold Spring Harb Perspect Med 2013; doi: 10.1101/cshperspect.a011858 originally published online February 6, 2013

\section{Subject Collection Hemoglobin and Its Diseases}

The Natural History of Sickle Cell Disease Graham R. Serjeant

Current Management of Sickle Cell Anemia Patrick T. McGann, Alecia C. Nero and Russell E. Ware

Cell-Free Hemoglobin and Its Scavenger Proteins: New Disease Models Leading the Way to Targeted Therapies Dominik J. Schaer and Paul W. Buehler

Clinical Manifestations of $\alpha$-Thalassemia Elliott $P$. Vichinsky

Erythroid Heme Biosynthesis and Its Disorders Harry A. Dailey and Peter N. Meissner

Hemoglobin Variants: Biochemical Properties and Clinical Correlates Christopher S. Thom, Claire F. Dickson, David A. Gell, et al.

The Prevention of Thalassemia Antonio Cao and Yuet Wai Kan

The Switch from Fetal to Adult Hemoglobin Vijay G. Sankaran and Stuart H. Orkin
Transcriptional Mechanisms Underlying Hemoglobin Synthesis

Koichi R. Katsumura, Andrew W. DeVilbiss, Nathaniel J. Pope, et al.

Iron Deficiency Anemia: A Common and Curable Disease Jeffery L. Miller

Management of the Thalassemias Nancy F. Olivieri and Gary M. Brittenham

The Molecular Basis of $\beta$-Thalassemia Swee Lay Thein

Erythropoiesis: Development and Differentiation Elaine Dzierzak and Sjaak Philipsen

Erythropoietin

H. Franklin Bunn

Classification of the Disorders of Hemoglobin Bernard G. Forget and H. Franklin Bunn

The Molecular Basis of $\alpha$-Thalassemia Douglas R. Higgs

For additional articles in this collection, see http://perspectivesinmedicine.cshlp.org/cgi/collection/ 